\title{
Review Article \\ Ruthenium Sensitizers and Their Applications in Dye-Sensitized Solar Cells
}

\author{
Yuancheng Qin ${ }^{1}$ and Qiang Peng, 2 \\ ${ }^{1}$ School of Environmental and Chemical Engineering, Nanchang Hangkong University, Nanchang 330063, China \\ ${ }^{2}$ College of Chemistry, Sichuan University, Chengdu 610064, China
}

Correspondence should be addressed to Qiang Peng, qiangpengjohnny@yahoo.com

Received 28 August 2011; Accepted 26 October 2011

Academic Editor: Newton Martins Barbosa Neto

Copyright ( 2012 Y. Qin and Q. Peng. This is an open access article distributed under the Creative Commons Attribution License, which permits unrestricted use, distribution, and reproduction in any medium, provided the original work is properly cited.

Dye-sensitized solar cells (DSSCs) have attracted considerable attention in recent years due to the possibility of low-cost conversion of photovoltaic energy. The DSSCs-based ruthenium complexes as sensitizers show high efficiency and excellent stability, implying potential practical applications. This review focuses on recent advances in design and preparation of efficient ruthenium sensitizers and their applications in DSSCs, including thiocyanate ruthenium sensitizers and thiocyanate-free ruthenium sensitizers.

\section{Introduction}

Energy is one of the most important factors to influence human life in the 21st century [1]. The great increasing consumption of fossil fuels, causing global warming and environmental pollution, has led to a greater focus on renewable energy sources and sustainable development. Solar cells, also called photovoltaic cells, are at the centre of an ongoing research effort to utilize the clean and renewable energy. The devices based on solar energy technology which convert sunlight directly into electricity are under the known photovoltaic effect. Today, standard solar panels based on multicrystalline silicon have power conversion efficiencies around 15\% [2]. However, the expensive investment and noneco friendly waste in semiconductor-processing technologies of the silicon-based solar cells have limited their popularization in our lives [3].

Dye-sensitized solar cells (DSSCs) have attracted considerable attention in recent years [2-8] because of their high incident solar light-to-electricity conversion efficiency, colourful and decorative natures, and low cost of production. DSSCs are based on the sensitization of mesoporous, nanocrystalline metal oxide films to visible light by the adsorption of organic molecular dyes. Following its discovery in 1991 [9], research on the DSSCs has progressed remarkably, rendering it a credible chemical alternative to solidstate silicon-based devices. Due to their high efficiency and stability, DSSCs were the first organic photovoltaic products to reach the market. G24 Innovations Limited (G24i), a U. K. company founded in 2006, uses DSSCs technology to manufacture and design solar modules. A DSSC (Figure 1) contains a fluorine-doped tin oxide $\left(\mathrm{SnO}_{2}: \mathrm{F}, \mathrm{FTO}\right)$ covered glass as anode, a thin and wide-band-gap oxide semiconductor mesoporous $\mathrm{TiO}_{2}$ film, an organic dye monolayer on the surface of the $\mathrm{TiO}_{2}$ layer deposited from its solution, an electrolyte or hole transport material fully covering the $\mathrm{TiO}_{2}$ /dye surface, and a counter electrode (such as platinum on glass for electrolyte-containing DSSCs or a silver or gold electrode for cells using organic hole-conducting materials) [10].

Ruthenium complexes have received particular interest as photosensitizers in DSSC application due to their favorable photoelectrochemical properties and high stability in the oxidized state, making practical applications feasible [11]. At present, state-of-the-art DSSCs based on ruthenium(II)polypyridyl complexes as the active materials have overall power conversion efficiencies over $11 \%$ under standard (Global Air Mass 1.5) illumination [12]. The high efficiencies of the ruthenium(II)-polypyridyl DSSCs can be attributed to their wide absorption range from the visible to the nearinfrared (NIR) regime. In addition, the carboxylate groups attached to the bipyridyl moiety lower the energy of the ligand $\pi^{*}$ orbital. The absorption spectra of ruthenium polypyridyl systems can be tuned by careful consideration 


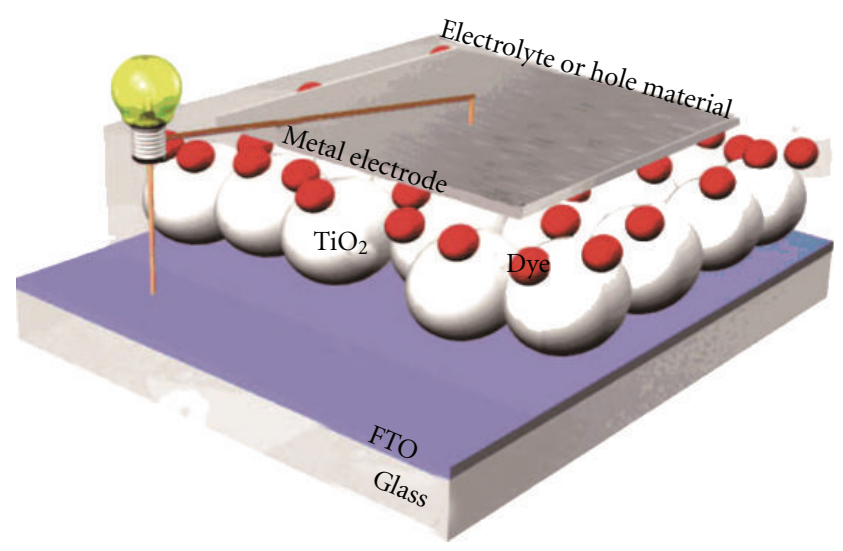

Figure 1: Diagram of typical dye-sensitized solar cell (taken from [10]).

of the HOMO and LUMO energy levels. We review in this paper on the development of ruthenium sensitizers and their potential applications in DSSCs.

\section{Thiocyanate Ruthenium Sensitizer for Solar Cells}

Ruthenium complexes, in particular, have been investigated intensively for DSSC applications since Regan and Grätzel reported the good device performance from a Ru complex dye in 1991 [9].

Tris $\left(2,2^{\prime}\right.$-bipyridyl)ruthenium(II) and its homologues have been extensively investigated as redox sensitizers, very little is known about the excited-state redox properties of the corresponding bis $\left(2,2^{\prime}\right.$-bipyridyl)ruthenium(II) analogous. Apart from their chemical stability and ease of interfacial charge exchange with semiconducting solids, the attractive feature of these complexes is their large visible light-harvesting capacity which is superior to that of the widely studied tris(bipyridyl) $\mathrm{Ru}(\mathrm{II})$ analogues, making them a judicious choice for solar energy conversion devices. Nazeeruddin et al. [13] have reported the first systematic study of the luminescence, visible light absorption, electrochemical, and photoredox properties of bis(bipyridyl) $\mathrm{Ru}(\mathrm{II})$ complexes having the general formula cis- $\mathrm{X}_{2}$ bis $\left(2,2^{\prime}\right.$ bipyridyl-4,4'-dicarboxylate)-ruthenium(II), where $\mathrm{X}=\mathrm{C} 1$, $\mathrm{Br}, \mathrm{I}, \mathrm{CN}$, and SCN. Among these compounds, cisdi(thiocyanato)bis(2,2-bipyridyl-4,4' -dicarboxylate) ruthenium(II) displays outstanding properties as a charge-transfer sensitizer, unmatched by any other dyestuff known so far. The broad range of visible light absorption and relatively long-lived excited state render it an attractive sensitizer for homogeneous and heterogeneous redox reactions. A thinlayer photoelectrochemical cell based on this system reached a 10\% AM 1.5 solar-to-electric conversion yield.

To improve further the efficiency of ruthenium sensitizers systems, an enhanced spectral response of the sensitizer in the red and near-IR region is required. The synthesis and characterization of a new class of trithiocyanato-ruthenium(II) terpyridyl complex were reported [14]. Substitution of the terpyridyl ligand by three carboxyl groups in $4,4^{\prime}, 4^{\prime \prime}$ positions yields a black dye displaying very efficient panchromatic sensitization over the whole visible range extending into the near-IR region up to $920 \mathrm{~nm}$.

In an effort to fulfill demanding requirements of the sensitizer, Nazeeruddin et al. [12] have succeeded in developing a panchromatic ruthenium complex sensitizer having carboxylated terpyridyl and three thiocyanate groups as ligands (Figure 2). The purpose of incorporating carboxylate groups in the ligand is threefold: (i) to increase the molar extinction coefficient of the complex, (ii) to facilitate the grafting of the dye on the semiconductor surface, and (iii) to ensure intimate electronic coupling between its excited-state wave function and the conduction band manifold of the semiconductor. On the basis of photovoltaic performance measured under full AM 1.5 sunlight, this black dye is superior to all charge-transfer sensitizers known thus far. At present the certified short circuit current under standard AM 1.5 sun light is $20.5 \mathrm{~mA} / \mathrm{cm}^{2}$, and the open-circuit voltage is $0.72 \mathrm{~V}$, yielding an overall conversion efficiency of $10.4 \%$. The discovery that the black dye exhibiting enhanced light harvesting in the red and near-IR region opens up the way to improve significantly the overall efficiency of nanocrystalline photovoltaic devices. The phenyl substitution should increase the molar extinction coefficient, permitting a reduction in film thickness which should benefit the open-circuit potential and overall efficiency of these solar cells.

Bach et al. [15] described a dye-sensitized heterojunction of $\mathrm{TiO}_{2}$ with the amorphous organic hole-transport material $2,2^{\prime}, 7,7^{\prime}$-tetrakis $(N, N$-di- $p$-methoxyphenyl-amine $) 9,9^{\prime}$ spirobifluorene. The methoxy groups are introduced in order to match the oxidation potential of the hole-transport medium (HTM) to that of the sensitizer $\mathrm{Ru}(\mathrm{II}) \mathrm{L}_{2}(\mathrm{SCN})_{2}$ (where $\mathrm{L}$ is $4,4^{\prime}$-dicarboxy-2,2' -bipyridyl). Photoinduced charge-carrier generation at the heterojunction is very efficient. A solar cell based on OMeTAD converts photons to electric current with a high yield of $33 \%$.

A convenient and versatile new route is reported for the synthesis of the heteroleptic ruthenium complex, which plays a key role in achieving the high-temperature stability [16]. The solar cell uses the amphiphilic ruthenium sensitizer of cis-RuLL' (SCN $)_{2}\left(\mathrm{~L}=4,4^{\prime}\right.$-dicarboxylic acid-2,2' -bipyridine, $\mathrm{L}^{\prime}=4,4^{\prime}$-dinonyl-2,2' -bipyridine) (Z907, Figure 3 ) in conjunction with a quasi-solid-state polymer gel electrolyte, reaching an efficiency of $>6 \%$ in full sunlight. The cell sustained heating for $1,000 \mathrm{~h}$ at $80^{\circ} \mathrm{C}$, maintaining $94 \%$ of its initial performance. The extraordinary stabilities of the device under both thermal stress and soaking with light match the durability criteria applied to solar cells for outdoor use, rendering these devices viable for practical application. A DSSC based on nanocrystalline $\mathrm{TiO}_{2}$ films that are covered by a mixed self-assembled monolayer of the amphiphilic Z907 sensitizer and 1-decylphosphonic acid (DPA) were also reported [17]. Long-term thermally stable devices with higher than $7 \%$ power conversion efficiency have been fabricated, and the photovoltage drop of the DSSC under heat stress has been greatly attenuated.

A $7.4 \%$ power conversion efficiency at air mass (AM) 1.5 full sunlight was reached with a mesoscopic solar cell 

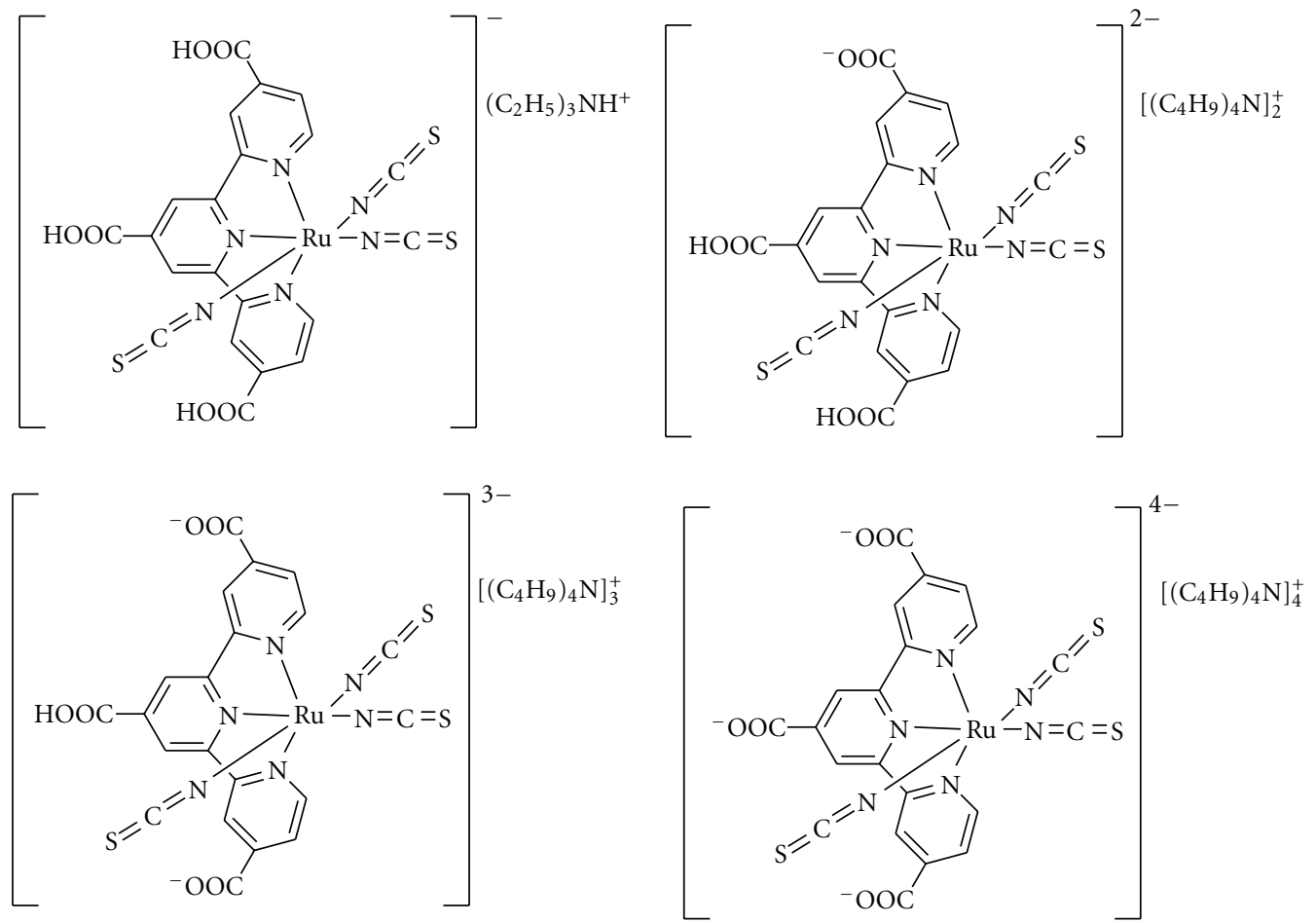

Figure 2: Molecular structures of ruthenium complexes (taken from [12]).

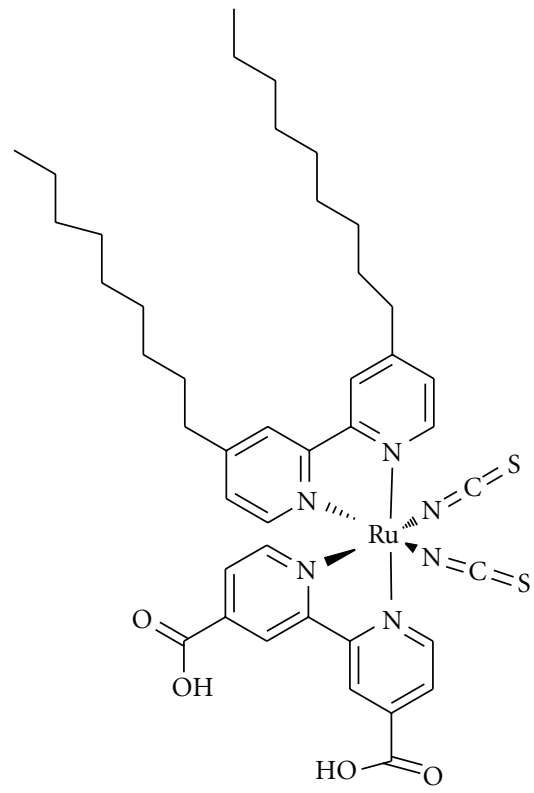

Figure 3: Molecular structure of Z907 (taken from [16, 17]).

employing a new binary ionic liquid electrolyte composed of 1-propyl-3-methylimidazolium iodide and 1-ethyl-3methylimidazolium tricyanomethanide in conjunction with the amphiphilic ruthenium complex $\mathrm{NaRu}$ (4-carboxylic acid-4' -carboxylate) $\left(4,4^{\prime}\right.$ - dinonyl-2,2' - bipyridine $)(\mathrm{NCS})_{2}$, coded as Z-907Na [18]. This heteroleptic Z-907Na sensitizer showed a relatively long lifetime of its oxidized state, which is highly desirable for practical application.

DSSCs based on swift self-assembled sensitizer bis(tetrabutylammonium)-cis-di(thiocyanato)- $N, N^{\prime}$-bis(4-carboxylato-4'-carboxylic acid-2,2'-bipyridine)ruthenium(II) (N719) on double layers of $12+4 \mu \mathrm{m}$ thick nanocrystalline $\mathrm{TiO}_{2}$ films exhibit the incident monochromatic photon-to-current conversion efficiency (IPCE) $90 \%$ and show a short circuit current density of $17 \mathrm{~mA} \mathrm{~cm}^{-2}$, open-circuit potential of $750 \mathrm{mV}$, and fill factor of 0.72 yielding power conversion efficiencies over $9.18 \%$ under AM 1.5 sun. For the first time, highest power conversion efficiencies are obtained for dye sensitized solar cells using a swift self-assembled procedure [19].

The significance of using amphiphilic polypyridyl ruthenium sensitizers has been demonstrated to achieve enhanced stability in DSSCs at elevated temperatures. Hence, it is interesting to design new ligands leading to the preparation of new amphiphilic ruthenium sensitizers. The molecular structure of the two new complexes $\left[\mathrm{Ru}(\mathrm{dcbpy})(\mathrm{L})(\mathrm{NCS})_{2}\right.$, where $\mathrm{L}$ is $\mathrm{N}, \mathrm{N}$-di(2-pyridyl)-dodecylamine, or N,N-di(2pyridyl)-tetradecylamine] are shown in Figure 4 [20]. Electrochemical studies have revealed that the oxidized state of this new type of dye is more stable than other polypyridyl ruthenium sensitizers with the thiocyanate ligand. Furthermore, these amphiphilic ruthenium complexes have been successfully used as sensitizers for nanocrystalline dye-sensitized solar cells with efficiencies of $8.2 \%$ at an $100 \mathrm{mWcm}^{-2}$ irradiance of air mass 1.5 solar light and $\geqq 8.7 \%$ at lower light intensities. The further work will be 


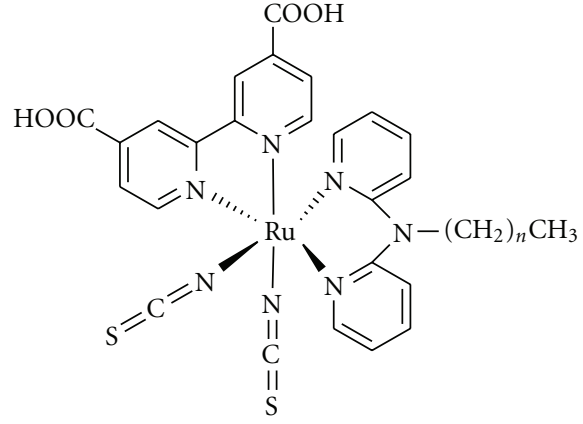

FIGURE 4: Molecular structures of complex I $(n=13)$ and complex II $(n=11)$ (taken from [20]).

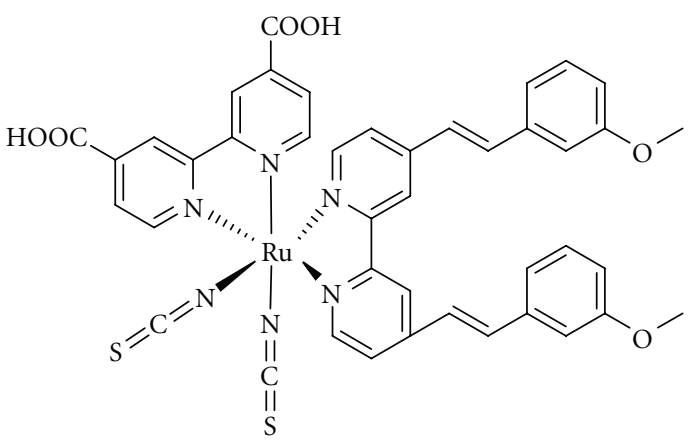

Figure 5: Molecular structure of Z910 (taken from [21]).

targeted to extend the conjugated system of the DPA-R ligand and thus to enhance the light-harvesting efficiency.

A new heteroleptic polypyridyl ruthenium complex of $\mathrm{Ru}(\mathrm{dcbpy})(\mathrm{dmsbpy})(\mathrm{NCS})_{2}$ referred to Z910 (Figure 5) with a high-molar extinction coefficient has been synthesized and demonstrated as a highly efficient, stable sensitizer for nanocrystalline solar cells [21]. For a newly developed dye, the achievement of $10.2 \%$ power conversion coefficient of sensitizers has been demonstrated to be an elegant strategy to improve the photovoltaic performance of DSSCs.

A combined experimental and theoretical study of ruthenium(II)-polypyridyl sensitizers for solar cell devices, derived from the $\left[\mathrm{Ru}\left(\mathrm{dcbpyH}_{2}\right)_{2}(\mathrm{NCS})_{2}\right], \mathbf{N} 3$, and $\left[\mathrm{Ru}\left(\mathrm{dcbpyH}_{2}\right)(\mathrm{tdbpy})(\mathrm{NCS})_{2}\right]$, N621 (Figure 6), complexes were presented [22]. On the experimental side, a purification procedure was developed to obtain pure $\mathrm{N}$-bonded isomers of both types of sensitizers. The photovoltaic data of the purified N3-derived $\left(\mathrm{Bu}_{4} \mathrm{~N}\right)_{2}\left[\mathrm{Ru}(\mathrm{dcbpyH})_{2}(\mathrm{NCS})_{2}\right] \quad$ N719 sensitizer adsorbed on $\mathrm{TiO}_{2}$ films in its monoprotonated state, exhibited a remarkable $11.18 \%$ power conversion efficiency at 1 sun. The calculated electronic structure in terms of molecular orbital energies and localization is consistent with the experimental redox potentials.

It is very important to develop transition-metal-based sensitizers with improved molar extinction coefficients which maintain the desirable stability under thermal stress and light soaking. Wang et al. [23] have reported a novel amphiphilic ruthenium complex coded as K19 (Figure 7) which accomplishes this goal. The photocurrent action spectrum of the K19 dye is presented in Figure 8. The enhanced absorption is expected by extending the conjugated system of the hydrophobic spectator ligand. The incident photon to current conversion efficiency (IPCE) exceeds $70 \%$ in a broad spectral range from 400 to $650 \mathrm{~nm}$, reaching a maximum of about $80 \%$ at $540 \mathrm{~nm}$. The short-circuit photocurrent density $\left(J_{\mathrm{sc}}\right)$, open-circuit photovoltage $\left(V_{\mathrm{oc}}\right)$, and fill factor (ff) under air mass (AM) 1.5 full sunlight are $14.61 \mathrm{~mA} \mathrm{~cm}^{-2}, 711 \mathrm{mV}$, and 0.671 , respectively, yielding an overall conversion efficiency $(\eta)$ of $7.0 \%$.

The influence of the hydrophobic hydrocarbon chain length of amphiphilic ruthenium dyes on the device performance in solid-state DSSCs [24]. By varying the hydrocarbon chain length of an amphiphilic ruthenium dye (Figure 9), the efficiency can be improved significantly. The results reported here suggest that a slightly longer hydrocarbon chain length might be advantageous and could lead to even higher efficiencies, and a hydrophobic chain attached to the dye can be used to suppress recombination. In the synthesis of dyes for dye-sensitized solar cells, this should be kept in mind.

An ion-coordinating sensitizer (K51, Figure 10) containing triethylene oxide methyl ether (TEOME) at the $4,4^{\prime}$-position of a 2,2-bipyridine ligand has been reported [25], which showed higher efficiency compared with a non ion-coordinating analogy (Z907). This "supermolecular complex" performs remarkably well when incorporated in a DSSC using a nonvolatile electrolyte or hole-transporting material, exhibiting a simulated full-sun power conversion efficiency of $7.8 \%$ or $3.8 \%$, respectively. K51 dye has an "ion-trapping" functionality, which inhibits the ions from reaching the $\mathrm{TiO}_{2}$ surface. Hence, in a liquid electrolyte device, there is little reduction in open-circuit voltage, and for the solid-state device there is a significant increase in the open-circuit voltage, when $\mathrm{Li}^{+}$is added. This should result in enhanced light-harvesting efficiency and thus higher photonto-electron conversion efficiencies.

Further, a high molar extinction coefficient ion-coordinating dye (K60) (Figure 10) was developed by extending the pi system of the peripheral ligand [26]. With this new sensitizer, photovoltaic power conversion efficiency of 8.4\% under AM 1.5-simulated sunlight at a light intensity of $100 \mathrm{mWcm}^{-2}$ has been obtained based on nonvolatility organic-solvent electrolyte. Photovoltaic performance over $9 \%$ was reached under low-light irradiance $\left(30 \mathrm{mWcm}^{-2}\right)$. These devices exhibit excellent stability when subjected to continuous thermal stress at $80^{\circ} \mathrm{C}$ or light soaking at $60^{\circ} \mathrm{C}$ for $1000 \mathrm{~h}$.

A new ion-coordinating ruthenium polypyridyl sensitizer, $\mathrm{NaRu}$ (4-carboxylic acid-4' -carboxylate) $\left(4,4^{\prime}\right.$-bis [ (triethyleneglycolmethylether) heptylether]-2,2'-bipyridine) (NCS) 2 (coded as K68) (Figure 9), has been synthesized [27]. The absorption shows that two MLCT absorption bands are at 528 and $380 \mathrm{~nm}$, their extinction coefficients being $11.4 \times$ $10^{-3}$ and $11.2 \times 10^{-3} \mathrm{M}^{-1} \mathrm{~cm}^{-1}$, respectively (Figure 11 ). A power conversion efficiency of $6.6 \%$ was obtained for DSSCs based on the $\mathbf{K} \mathbf{6 8}$ dye and a newly developed binary 


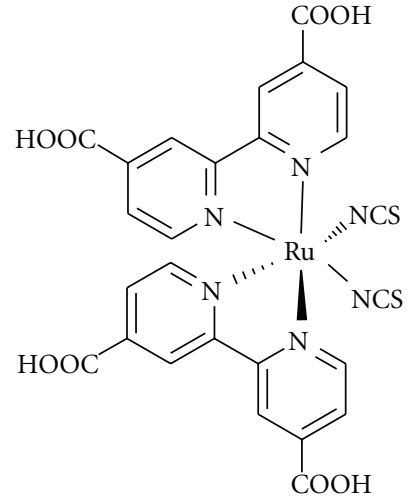

N3

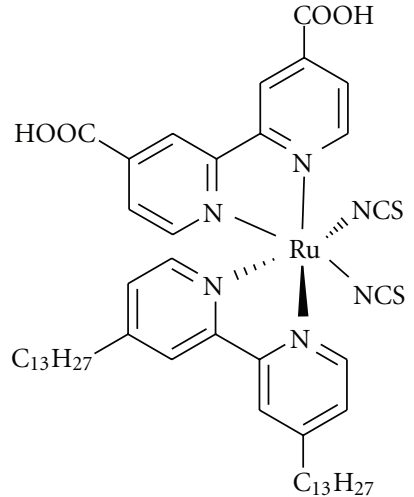

N621

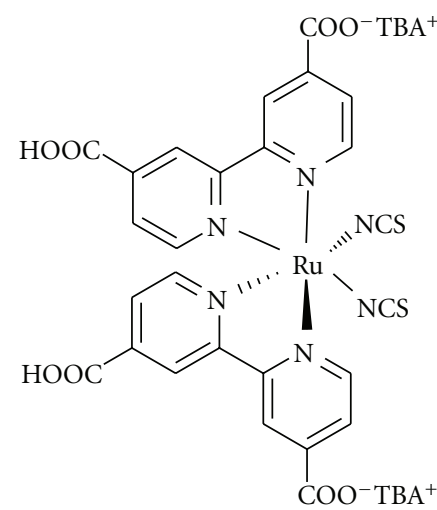

N719

FIgURE 6: Molecular structures of N3, N621, and N719 dyes (taken from [22]).<smiles></smiles>

Figure 7: Molecular structure of the K19 sensitizer (taken from $[23])$.

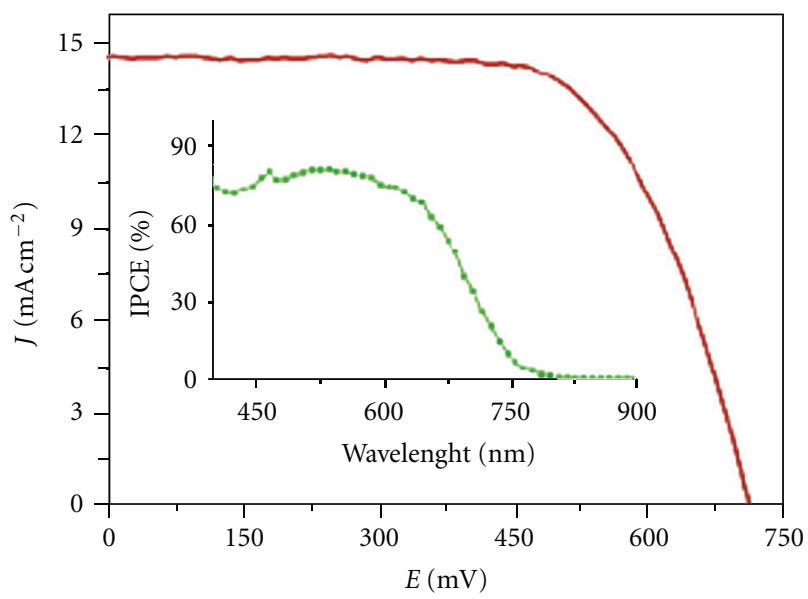

Figure 8: Photocurrent density-voltage characteristics under AM 1.5 full sunlight $\left(100 \mathrm{mWcm}^{-2}\right)$ (taken from [23]).

ionic liquid electrolyte containing 1-propyl-3-methyl-imidazolium iodide (PMII) and 1-ethyl-3-methyl-imidazolium tetracyanoborate $\left(\mathrm{EMIB}(\mathrm{CN})_{4}\right)$. DSSCs incorporating the K68 dye also exhibit a better thermal stability than the K51 dye, due to the increased hydrophobicity.
The advantage of high extinction coefficient sensitizers is in realizing efficient thin film solar cells. The two novel high molar extinction coefficient ruthenium dyes with $\mathrm{Ru}\left(\left(4,4\right.\right.$-dicarboxylic acid-2,2' -bipyridine) $\left(4,4^{\prime}\right.$-bis(p-hexyloxystyryl)-2,2-bipyridine)(NCS $\left.)_{2}\right)$ (K19) and without amphiphilic chains $\mathrm{Ru}((4,4$-dicarboxylic acid-2,2' -bipyridine) $\left.\left(4,4^{\prime} \text {-bis(p-methoxystyryl)-2,2' -bipyridine)(NCS }\right)_{2}\right) \quad$ (K73) presented show very attractive features with regards to photovoltaic performance and stability [28]. Devices based on the K73 dye and a nonvolatile electrolyte yielded an unprecedented overall conversion efficiency of $9 \%$ under AM 1.5 global sunlight. Solar cells employing the K19 dye in combination with a binary ionic liquid electrolyte gave over $7.0 \%$ efficiency and maintained excellent stability under light soaking at $60^{\circ} \mathrm{C}$ for $1000 \mathrm{~h}$.

Exploring lateral charge transport in self-assembled monolayers (SAMs) of redox-active molecules is of particular interesting [29]. As indicated schematically in Figure 12, a monolayer of redox-active molecules is adsorbed on the surface of a nanocrystalline oxide film, which is deposited on a conducting glass. Ruthenium polypyridyl complexes attached onto mesoscopic oxide films are of particular interest as they remain to date the most efficient sensitizers for dye-sensitized solar cells. The bipyridyl ligands of the Rucomplex transport electrons, while the NCS groups play a pivotal role in mediating surface-confined hole percolation. Cyclic voltammetric, spectroelectrochemical, and impedance measurements were applied to determine the percolation threshold and rate for cross-surface hole transfer.

Modification of the dye is one of the essential strategies to improve the performance of DSSCs. Efforts have been made to further improve the cell performance achieved with the N3 dye. New efficient dyes, D6 and D5 (Figure 13) containing oligophenylenevinylene $\pi$-conjugated backbones, each with one $N, N$-dibutylamino moiety were synthesized [30]. D5 and D6 enabled about 12\% and 17\% enhancements in solarto-electricity conversion efficiency, respectively, for their DSSCs, compared to the efficiency obtainable with N3 dye. The enhancements are correlated with higher molar absorption coefficients of these sensitizers with respect to those 


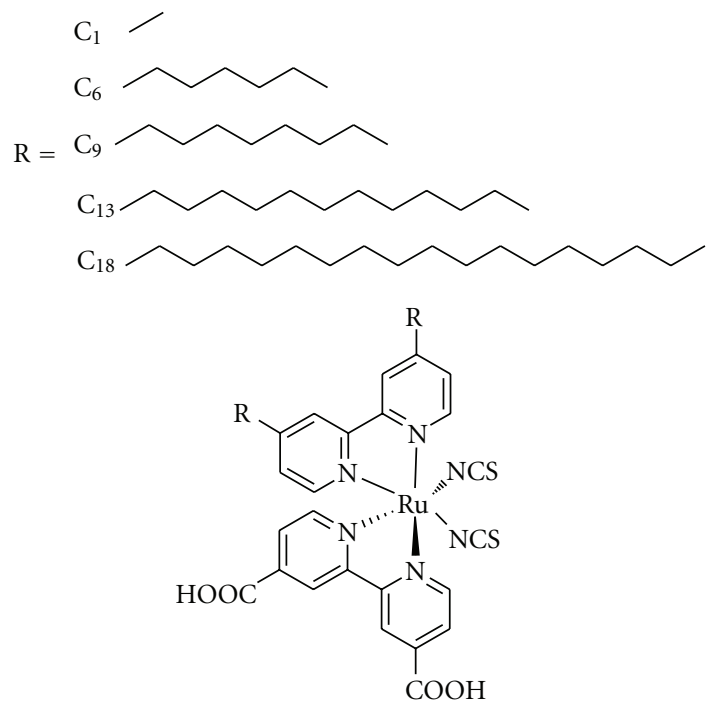

(a)

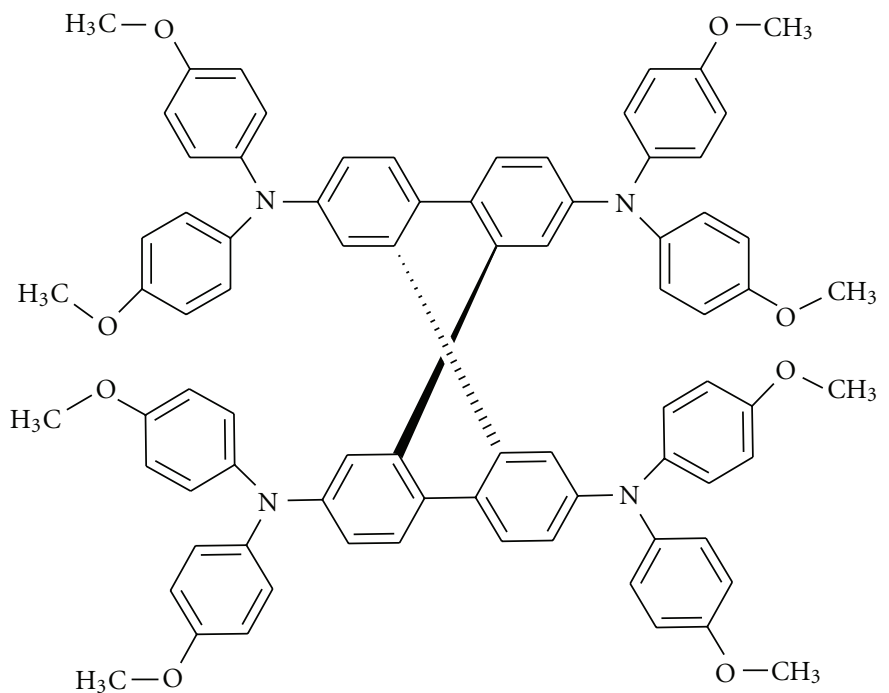

(b)

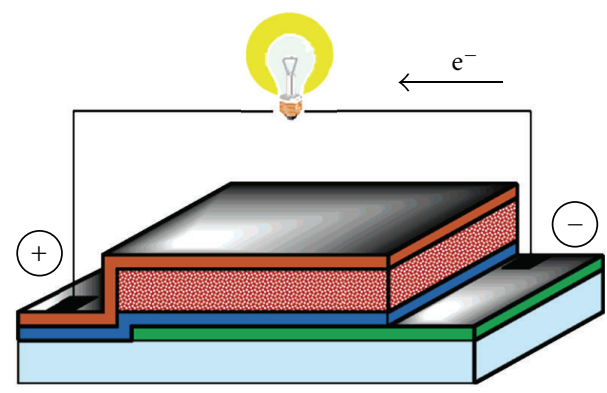

(c)

Figure 9: Molecular structures of the dyes with different chain lengths (a) and the hole conductor (b) used for the device preparation are shown next to a schematic of the device structure (c) the devices consist of a glass substrate covered by a conductive transparent electrode (F-doped $\mathrm{SnO}_{2}$ ) (taken from [24]).

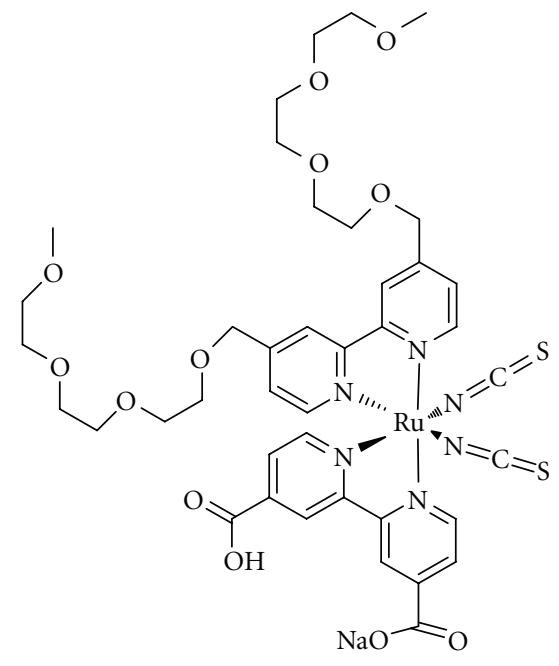

K51

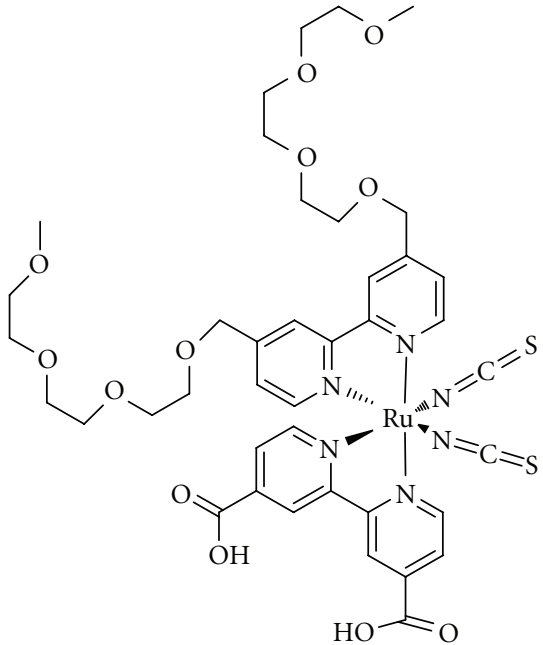

K60

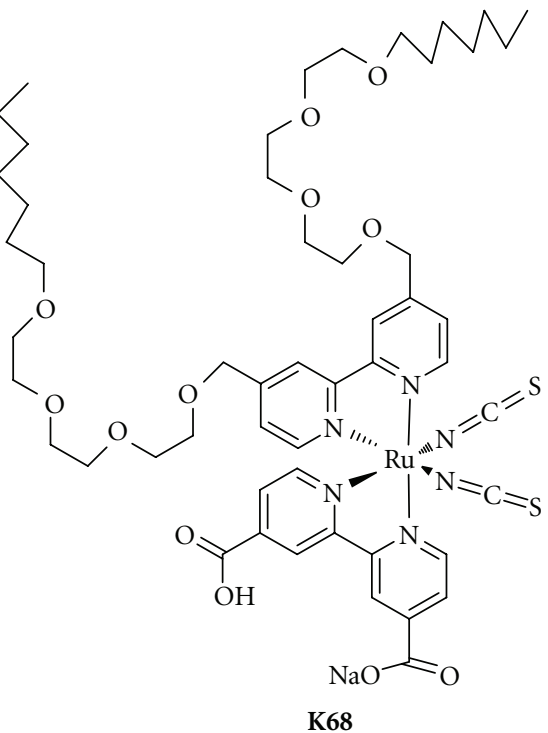

K68

Figure 10: Molecular structures of K51, K60, and K68 dyes (taken from [26]). 


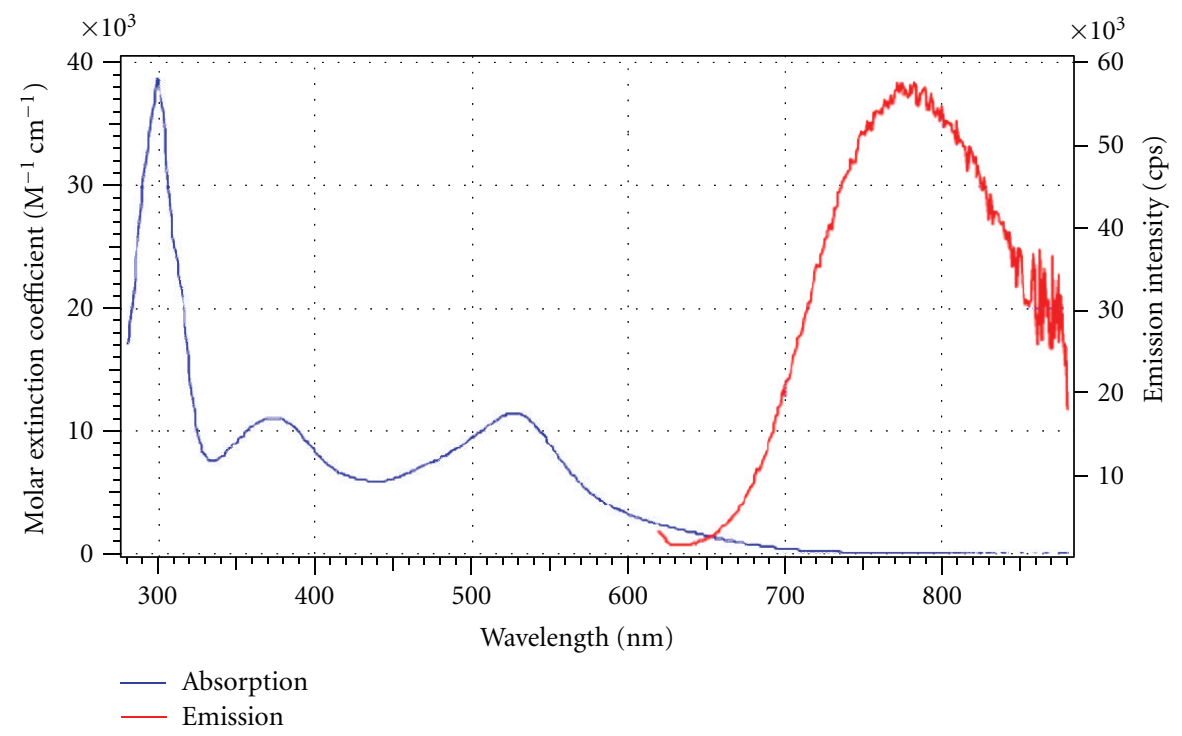

FIGURE 11: Electrical absorption and emission spectra of the K68 sensitizer in DMF solution (taken from [27]).
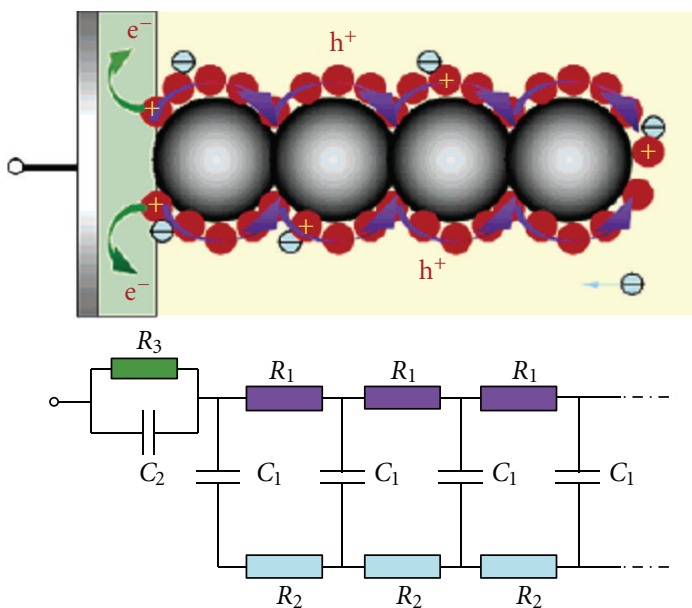

FIGURE 12: Schematic model showing the cross-surface charge percolation through the molecular monolayer adsorbed on mesoscopic oxide films (taken from [29]).

of $\mathbf{N} 3$ over the visible spectral region, due to the presence of oligophenylenevinylene groups with $\mathrm{N}, \mathrm{N}$-dibutylamino moieties in these sensitizers.

To improve the power conversion efficiency of DSSCs by molecular engineering of a Ru-based photosensitizer, the reported CYC-B1 (Figure 14) compound is a representative ruthenium complex with high current density and conversion efficiency [31].

The novel 2-thiophen-2-yl-vinyl-conjugated ruthenium sensitizer (HRS-1) (Figure 15) was synthesized and shows respectable light-harvesting performance in the visible-light region, and a reversible, one-electron oxidation process [32]. The HRS-1-based DSSCs give a higher solar light to electricity conversion efficiency compared to N719-based DSSCs under comparable conditions.

The optimization of interfacial charge transfer between the dye and the electrolyte is crucial to the design of dye-sensitized solar cells. Kawano et al. [33] address the combined use of an ionic liquid crystal electrolyte and amphiphilic ruthenium dyes in dye-sensitized solar cells. The solar cell, with an amphiphilic ruthenium dye $\left[\mathrm{Ru}\left(\mathrm{H}_{2} \mathrm{dcbpy}\right)(\mathrm{tdbpy})(\mathrm{NCS})_{2}\right]$ (Figure 16), exhibited a short-circuit photocurrent density of $9.1 \mathrm{~mA} / \mathrm{cm}^{2}$, an opencircuit voltage of $665 \mathrm{mV}$, and a fill factor of 0.58 , corresponding to an overall conversion efficiency of 3.51\%. The optimization of nanostructured dye-sensitized solar cell efficiency ultimately depends on meticulous design of interface between the dye and the liquid crystal electrolyte.

De Angelis et al. [34] have confirmed an injection mechanism for $\mathrm{Ru}(\mathrm{II})$ dyes on $\mathrm{TiO}_{2}$ mediated by the dyeexcited states and indicates a remarkable effect of dye protonation on the electronic properties of N719-sensitized $\mathrm{TiO}_{2}$ nanoparticles. They find that two different electron injection mechanisms may be present in DSSCs employing 


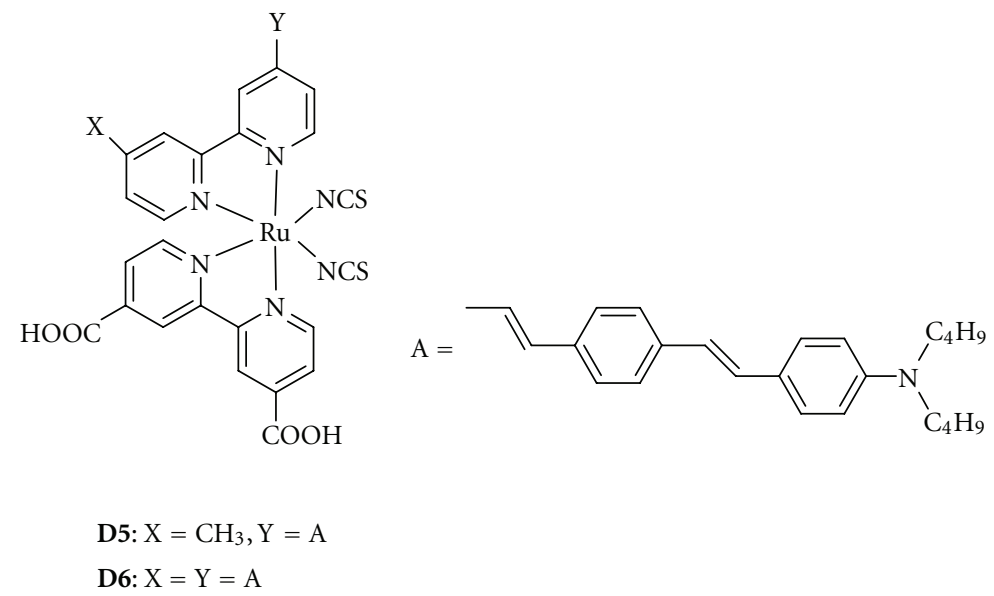

Figure 13: Molecular structures of D5 and D6 (taken from [30]).

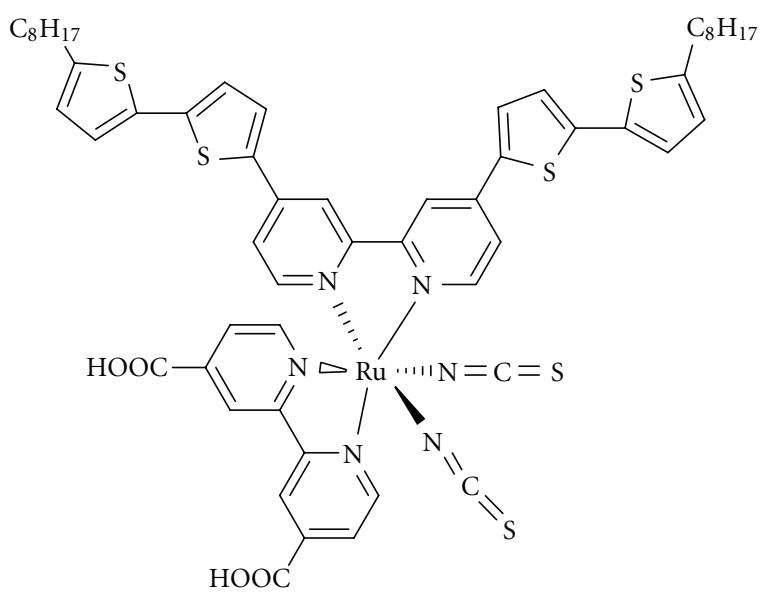

FIgURE 14: Molecular structure of CYC-B1 (taken from [31]).

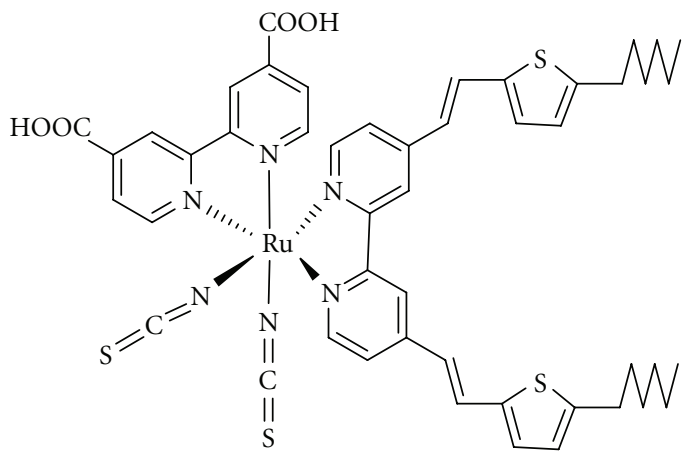

FIGURE 15: Molecular structure of the new sensitizer, HRS-1 (taken from [32]).

dyes carrying a different number of protons: the strong coupling of the dye/ $/ \mathrm{TiO}_{2}$-excited states computed upon $\mathrm{TiO}_{2}$ protonation suggests that an adiabatic injection mechanism, in which the same electronic state changes its localization from the dye to the $\mathrm{TiO}_{2}$, might be responsible for the high rates of electron injection observed experimentally for $\mathrm{Ru}-$ polypyridyl dyes on $\mathrm{TiO}_{2}$.

To obtain bpy donor antenna groups with extended p-electron delocalization, electron-rich donor molecules, novel ruthenium dyes, Ru-TPANCS, and Ru-TPD-NCS (Figure 17) with electron-donor antenna groups (triphenyl amine and tetraphenylbenzidine) were developed [35]. These dyes were applied in all-solid-state dye-sensitized solar cells and displayed remarkably higher efficiencies of 3.4\% and $1.5 \%$ when compared to the cell fabricated with standard N719 dye $(0.7 \%)$.

In order to improve the photovoltaic performance and stability of DSSCs, extensive efforts have been focused on the synthesis of new highly efficient sensitizers. Thus, a new sensitizer-, $\mathrm{Ru}$ (2,2' -bipyridine-4,4' -dicarboxylic acid) (4,4' bis(2-(4-tert-butyloxy-phenyl)ethenyl)-2,2' -bipyridine) $(\mathrm{NCS})_{2}$, denoted K77 (Figure 18) were reported [36]. Mesoscopic DSSCs with more than a $10.5 \%$ photoelectrical conversion efficiency were obtained utilizing the designed high molar extinction coefficient sensitizer (K77) in conjunction with a volatile electrolyte (Z675). Highly efficient DSSCs (up to 9.5\%) exhibiting unprecedented long-term stability $(1000 \mathrm{~h})$ under both light soaking and thermal stressing have been obtained using the K77 sensitizer in combination with a newly formulated nonvolatile organicsolvent-based electrolyte (Z646).

Elongating the conjugation length of the anchoring or ancillary ligand is the best route to improve the molar extinction coefficient of the sensitizers. Chen et al. [37] reported the synthesis and performance of two new well-designed ruthenium complexes, SJW-E1 and CYC-B3 (Figure 19). The structures of SJW-E1 and CYC-B3 incorporate $\alpha$-octylethylene-dioxythiophene (O-EDOT) and octyl-thiophenesubstituted bipyridine, respectively, as ancillary ligands. The CYC-B3-sensitized solar cell has a short-circuit photocurrent density of $15.7 \mathrm{~mA} \mathrm{~cm}^{-2}$, open-circuit potential of $0.669 \mathrm{~V}$, and fill factor of 0.705 , yielding power conversion efficiencies of $7.39 \%$. The SJW-E1-sensitized solar cell gave a very high 


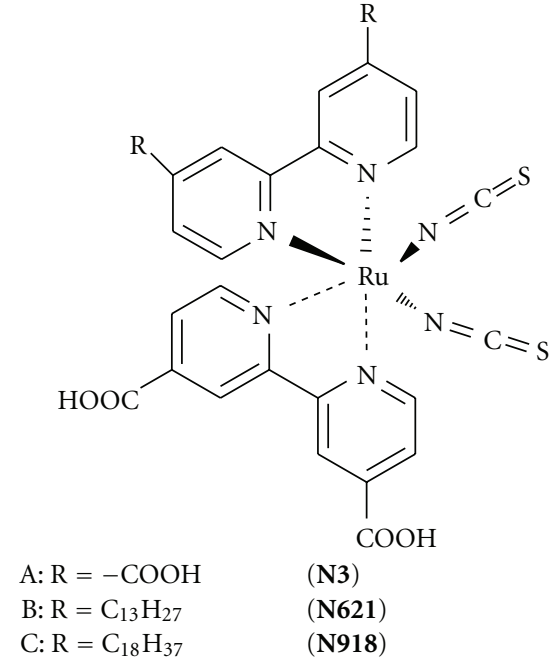

(a)

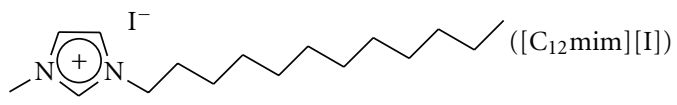

(b)

Figure 16: Molecular structures of (a) ruthenium dyes (A: N3, B: N621, and C: N918), and (b) an ionic liquid crystal ([C $\left.\left.\mathrm{C}_{12} \mathrm{mim}\right][\mathrm{I}]\right)$ (taken from [33]).

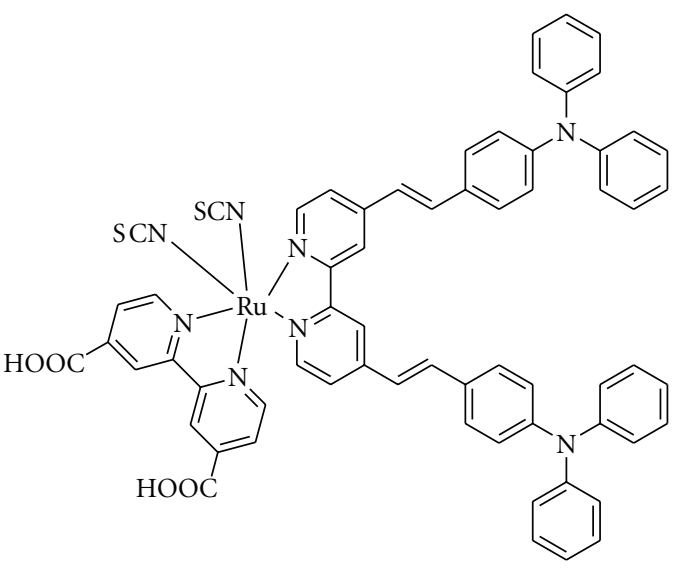

(a)

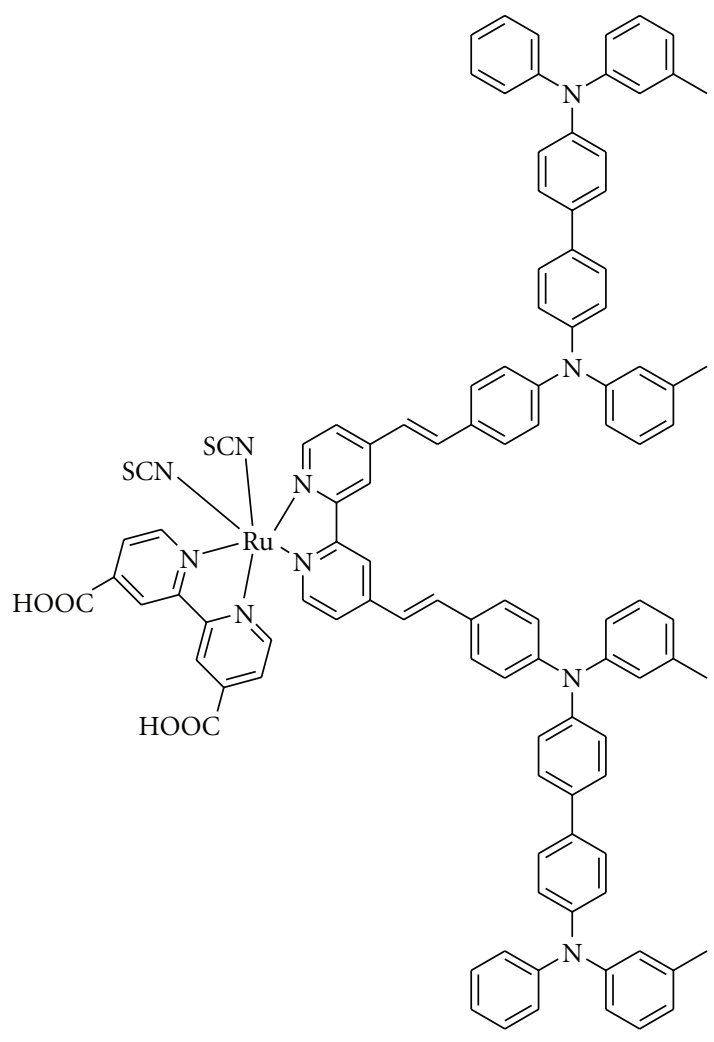

(b)

FIgURE 17: Molecular structures of (a) Ru-TPA-NCS, and (b) Ru-TPD-NCS (taken from [35]).

photocurrent density of $21.6 \mathrm{~mA} \mathrm{~cm}^{-2}$ and $\eta=9.02 \%$. The significant increase in $\eta$ value for SJW-E1- compared to CYC-B3-sensitized solar cells revealed the important role of the EDOT moiety in the ancillary ligand of the ruthenium complex. The difference in the performance demonstrates that molecular engineering of the ancillary ligands of the ruthenium complexes to achieve higher performance could be expanded from one-dimensional extension of the conjugation length to two-dimensional conjugation enhancement and functional group substitution. 


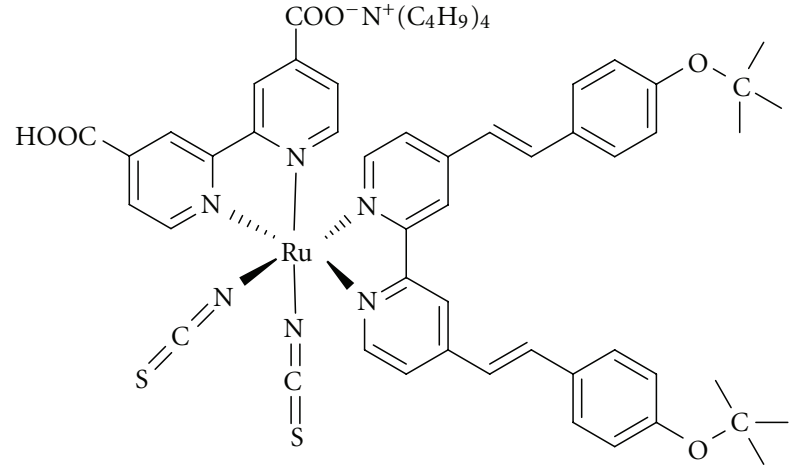

FIGURE 18: Molecular structure of the K77 sensitizer (taken from [36]).

For commercial applications of DSSCs, it is necessary to employ nonvolatile or even solvent-free electrolytes. However, with a low-fluidity electrolyte, the charge collection yield becomes low due to the shortened electron diffusion length. Enhancing the optical absorptivity of a stained mesoporous film can counter this effect. Two new heteroleptic polypyridyl ruthenium complexes, coded C101 and C102 (Figure 20), with high molar extinction coefficients have been synthesized and demonstrated as efficient sensitizers [38]. The optical absorptivities of mesoporous titania film have been enhanced with these sensitizers by extending the $\pi$-conjugated system of ancillary ligands. On the basis of the new C101 sensitizer, several new DSC benchmarks under the illumination of AM $1.5 \mathrm{G}$ full sunlight have been reached, such as a $11.0 \%$ efficiency along with an acetonitrile-based electrolyte, a long-term stable $>9 \%$ device using a lowvolatility electrolyte, and a long-term stable about $7.4 \%$ device employing an ionic liquid electrolyte.

Two series of novel ruthenium bipyridyl dyes incorporating sulfur-donor bidentate ligands with general formula $\left[\mathrm{Ru}(\mathrm{R}-\mathrm{bpy})_{2}\left(\mathrm{C}_{2} \mathrm{~N}_{2} \mathrm{~S}_{2}\right)\right]$ and $\left[\mathrm{Ru}(\mathrm{R}-\mathrm{bpy})_{2}\left(\mathrm{~S}_{2} \mathrm{COEt}\right)\right]\left[\mathrm{NO}_{3}\right]$ (where $\mathrm{R}=\mathrm{H}, \mathrm{CO}_{2} \mathrm{Et}, \mathrm{CO}_{2} \mathrm{H} ; \mathrm{C}_{2} \mathrm{~N}_{2} \mathrm{~S}_{2}=$ cyanodithioimidocarbonate and $\mathrm{S}_{2} \mathrm{COEt}=$ ethyl xanthogenate) (Figure 21) have been synthesized and characterized spectroscopically, electrochemically, and computationally [39]. The acid derivatives in both series $\left(\mathrm{C}_{2} \mathrm{~N}_{2} \mathrm{~S}_{2} 3\right.$ and $\mathrm{S}_{2}$ COEt 6 ) were used as photosensitizers in DSSCs, and the incident photo-tocurrent conversion efficiency (IPCE), overall efficiency $(\eta)$, and kinetics of the dye/ $/ \mathrm{TiO}_{2}$ system were investigated in detail. $\left[\mathrm{Ru}(\mathrm{dcbpy})_{2}\left(\mathrm{~S}_{2} \mathrm{COEt}\right)\right]^{+}(\mathbf{6})$ showed an efficiency of $1.2 \%$ in an unoptimized DSSC. It is apparent that complexes within this family can possess very attractive features for sensitizers in DSSC. Modification of the sulfur-donor ligand has been shown to enable enhanced electronic characteristics and chelating ligands can offer enhanced dye stability. The challenge for subsequent studies will be the combination of these various positive features into a dye, while avoiding inadvertent detrimental effects such as the rapid recombination observed for 3 .

An amphiphilic bipyridyl ligand, 4,40-dicarboxy-octyl2,20-bipyridine, and its ruthenium complex (termed as $\mathbf{S 8}$ ) were synthesized (Figure 22) [40]. The $\mathbf{S 8}$ gave a photocurrent density of $13.02 \mathrm{~mA} / \mathrm{cm}^{2}$, open-circuit voltage of $0.60 \mathrm{~V}$, and fill factor of 0.69 yielding 5.36\% efficiency. The S8 dye with aliphatic chain improved conversion efficiency of the resulting DSSCs compared with a cell fabricated using the N3 dye. Efficiency improvement of the devices with the $\mathbf{5 8}$ dye is due to aliphatic chain of $\mathbf{S 8}$ linking to carboxylate group of ligand. The aliphatic chains act as an effective electron donor, and carboxylate group acts as an effective electron withdrawing between the $\mathrm{TiO}_{2}$ layer and the carboxylate linking $\mathrm{TiO}_{2}$ layer leading to increasing of electron density at this interface. Increased electron injection is reflected in the enhanced efficiency.

To improve their effectiveness in both the visible and near-IR regions, Funaki et al. [41] synthesized a new class of cyclometallated ruthenium(II) complexes (Figure 23). These compounds can be used in DSSCs. A DSSC sensitized with 8 shows a $10 \%$ incident photon-to-current conversion efficiency at $900 \mathrm{~nm}$.

In line with the continuation of the efforts in this direction for improving the power conversion efficiency, A new type of the ruthenium sensitizer JK-91 and JK-92 (Figure 24), consisting of triazole moiety as a bridging group, was synthesized using click chemistry [42]. The general idea is to use the triazole group for extending the $\pi$-conjugated backbone. Figure 25 shows action spectra of monochromatic incident photo-to-current conversion efficiencies (IPCEs) for DSSCs based on JK-91 and JK-92 using an acetonitrilebased electrolyte. The power conversion efficiencies of the DSSCs based on the JK-91 and JK-92 can reach the values of 6.22 and $6.75 \%$.

Since the first isolation and characterization of free $\mathrm{N}$ heterocyclic carbene (NHC) [43], many advances have been made on the syntheses, reactions, and applications of NHCs bearing a unique set of electronic properties [44]. It could be encouraging to replace the bipyridine ligand of the bipyridyl or polypyridyl complexes with neutral NHC ligands. Novel NHC-pyridine ruthenium sensitizers (Figure 26) were successfully designed and synthesized [45, 46]. These sensitizers result in efficient DSSCs with good sensitizing capability. These complexes showed photoelectric conversion efficiencies in the range of 6.43-9.69\%.

Recently, many efforts have been made to change the ligands of $\mathrm{Ru}$ complexes and optimize the photosensitizers. A series of heteroleptic ruthenium complexes $\left[\mathrm{Ru}\left(4,4^{\prime}\right.\right.$-carboxylic acid-2,2' -bipyridine)(L)(NCS $\left.)_{2}\right]\left(\mathrm{L}=5,5^{\prime}\right.$-bis(4-octylthiophen-2-yl)-2,2' -bipyridine (9), 5,5' -bis (N,N-diphenyl4-aminophenyl)-2,2' -bipyridine (10), 5,5'-bis $(5-(N, N$-diphenyl-4-aminophenyl)-thiophen-2-yl)-2,2'-bipyridine (11), and 5,5'-bis(4-octyl-5-(N,N-diphenyl-4-aminophenyl)-thiophen-2-yl)-2,2' -bipyridine (12)) (Figure 27) were synthesized [47]. The maximum incident photon to current conversion efficiency (IPCE) of $41.4 \%$ at $550 \mathrm{~nm}, 38.6 \%$ at $480 \mathrm{~nm}, 39.4 \%$ at $470 \mathrm{~nm}$, and $31.1 \%$ at $480 \mathrm{~nm}$ for 9-, 10-, 11-, and 12-sensitized solar cells were obtained. Respectable power conversion efficiencies of $3.00 \%, 2.51 \%, 2.00 \%$ and $2.03 \%$ were obtained, respectively, when the sensitizers $\mathbf{9}, \mathbf{1 0}$, 11 and 12 were used in DSSCs under the standard air mass (AM) 1.5 sunlight illumination. 


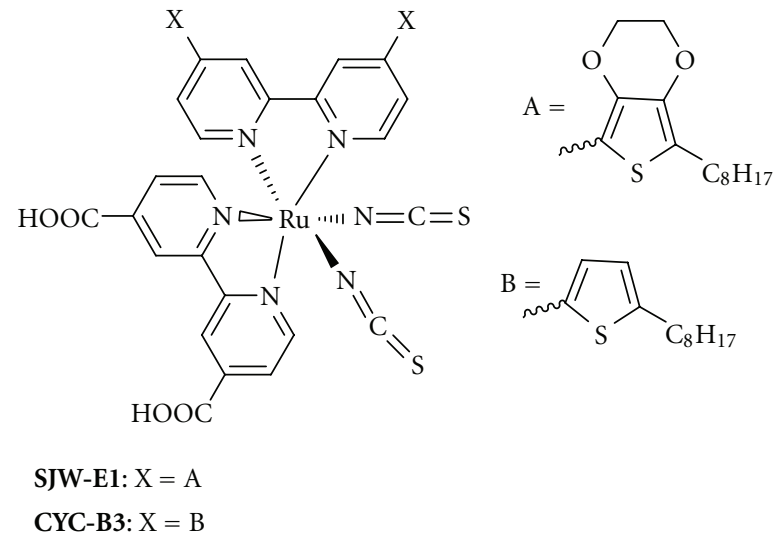

Figure 19: Molecular structures of SJW-E1 and CYC-B3 (taken from [37]).

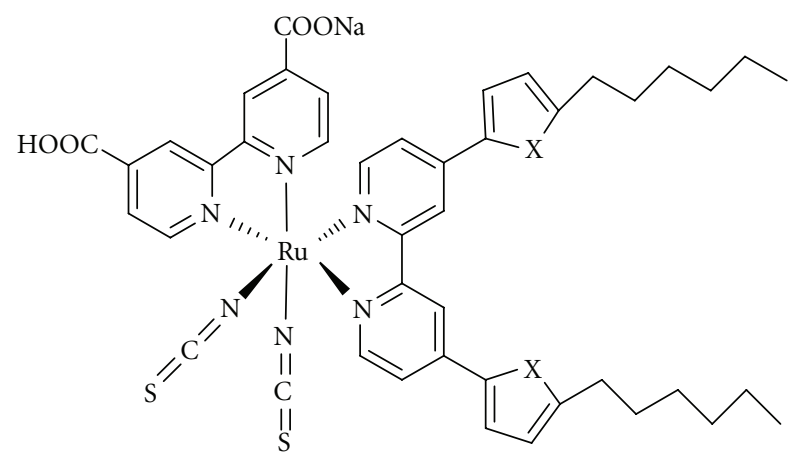

Figure 20: Molecular structures of the C101 $(\mathrm{X}=\mathrm{S})$ and C102 (X = O) sensitizers (taken from [38]).

Three alkyl-substituted $\beta$-diketonato-ruthenium(II)polypyridyl sensitizers with different alkyl chain lengths, [Ru(tctpy)(tfpd)(NCS)] (A1), [Ru(tctpy)(tfdd)(NCS)] (A2), and $[\mathrm{Ru}(\mathrm{tctpy})(\mathrm{tfid})(\mathrm{NCS})]$ (A3) (Figure 28), were designed and synthesized by Islam et al. [48]. These dyes showed gradually enhanced photovoltaic performance with increasing the alkyl chain length. The photovoltaic data of these new complexes show $7.6 \%$ power conversion efficiency under standard AM 1.5 irradiation $\left(100 \mathrm{mWcm}^{-2}\right)$.

New ruthenium polypyridine sensitizers, T18 and A597 (Figure 29) for DSSCs, were synthesized with ancillary ligands $[49,50]$. The T18 dye has a red-shifted and larger MLCT absorption coefficient, and the A597 complex has competitive visible light absorption and tunable redox behaviour.

The modification of the ancillary bipyridine ligands in ruthenium(II) heteroleptic complexes by means of tedious synthesis may not be practical in light of the high cost of ruthenium metal [47]. Yen et al. [51] have attempted to use readily available aromatic segments to extend the conjugation of the ancillary ligand while also meeting cost-effective requirements. In view of the fact that DSSCs based on Z907 exhibit excellent stability toward dye leaching and high $V_{\mathrm{oc}}$
TABle 1: Performance parameters of the YS-1-YS-5 dyes in DSSCs (taken from [51]).

\begin{tabular}{lcccc}
\hline Dye & $J_{\text {SC }}\left[\mathrm{mA} \mathrm{cm}^{-2}\right]$ & $\mathrm{V}_{\text {OC }}[\mathrm{V}]$ & $\mathrm{FF}$ & $\eta[\%]$ \\
\hline YS-1 & 13.01 & 0.66 & 0.69 & 5.94 \\
YS-2 & 14.08 & 0.69 & 0.63 & 6.44 \\
YS-3 & 15.90 & 0.70 & 0.62 & 6.91 \\
YS-4 & 14.72 & 0.68 & 0.66 & 6.63 \\
YS-5 & 15.40 & 0.64 & 0.66 & 6.60 \\
Z907 & 14.16 & 0.68 & 0.66 & 6.36 \\
N719 & 15.17 & 0.71 & 0.66 & 7.13 \\
\hline
\end{tabular}

value, it would also be of interest to develop and explore ruthenium sensitizers with hydrocarbon chains in the lateral direction of the ancillary ligands. The presence of these hydrocarbon chains should improve the solubility of the complexes in common organic solvents. Five ruthenium sensitizers, YS-1-YS-5, which incorporate fluorene-, carbazole-, and dithieno[3,2-b:2' $3^{\prime}$-d] pyrrole-substituted bipyridine as the ancillary ligand were prepared (Figure 30 ). DSSCs based on these sensitizers were fabricated and compared with Z907-based devices. These complexes exhibit very impressive conversion efficiencies (5.94 to $6.91 \%$ ) that surpass the value of Z907 $(6.36 \%)$ and are comparable with that of N719 (7.13\%) under similar conditions (Table 1).

\section{Thiocyanate-Free Ruthenium Sensitizer}

The thiocyanate ligands are usually considered as the most fragile part of the ruthenium dyes [8]. Firstly, since it is a monodentate ligand, it is easier to decoordinate than a bidentate ligand like bipyridine. Secondly, it is an ambidentate ligand which can attach at either the sulfur atom or the nitrogen atom. Many attempts to replace the thiocyanate donor ligands have been made. This thiocyanate-free ruthenium sensitizer builds on a report by Wadman et al. [52] that provides an impetus to investigate this class of compounds in further detail. 


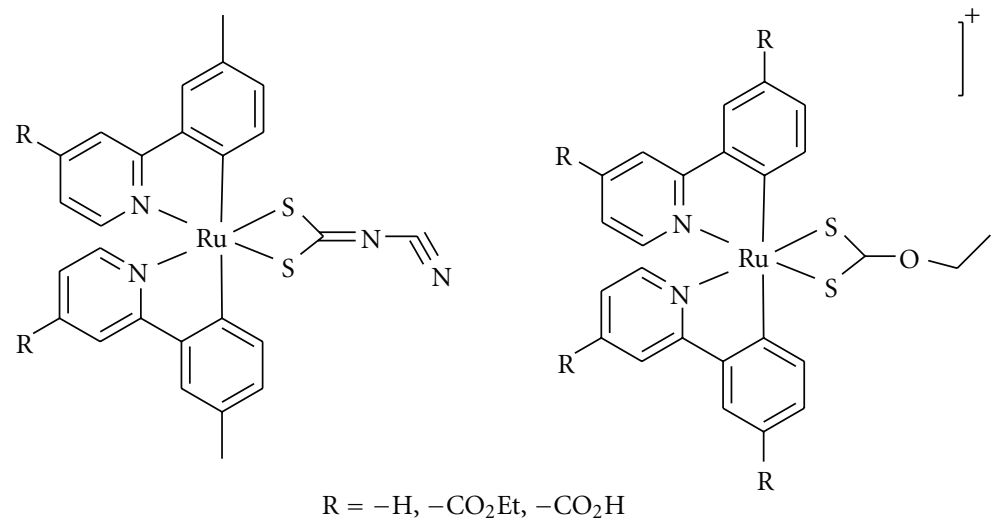

Figure 21: Molecular structures of $\left[\mathrm{Ru}(\mathrm{R}-\mathrm{bpy})_{2} \mathrm{C}_{2} \mathrm{~N}_{2} \mathrm{~S}_{2}\right]\left(\mathrm{R}=\mathrm{H}(\mathbf{1}), \mathrm{CO}_{2} \mathrm{Et}(\mathbf{2})\right.$, and $\left.\mathrm{CO}_{2} \mathrm{H}(\mathbf{3})\right)$ and $\left[\mathrm{Ru}(\mathrm{R}-\mathrm{bpy})_{2}\left(\mathrm{~S}_{2} \mathrm{COEt}\right)\right]\left[\mathrm{NO} \mathrm{C}_{3}\right](\mathrm{R}=\mathrm{H}$ (4), $\mathrm{CO}_{2} \mathrm{Et}(5)$, and $\mathrm{CO}_{2} \mathrm{H}(6)$ ) (taken from [39]).
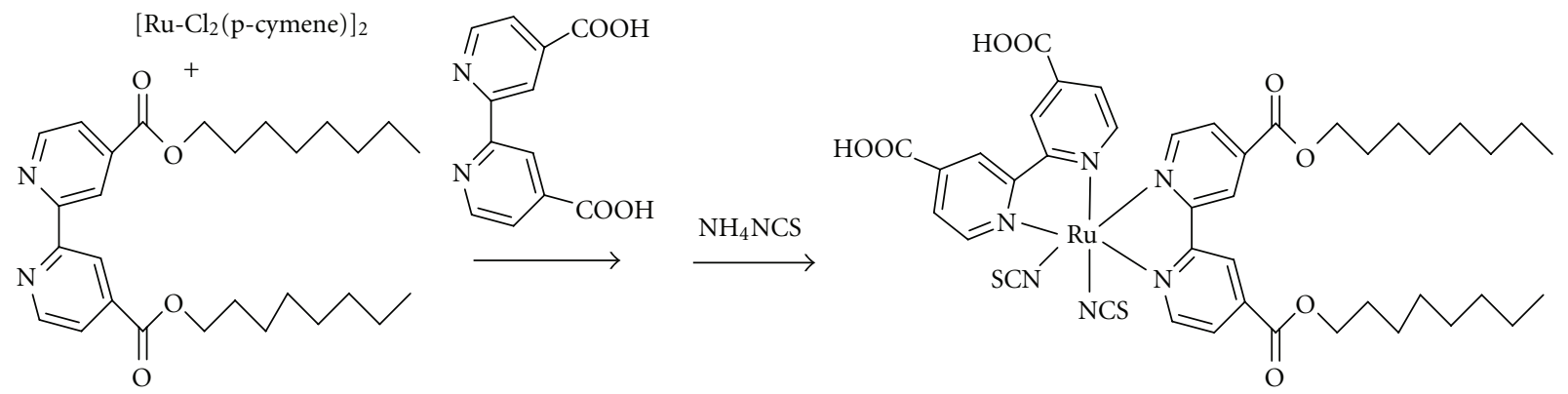

Figure 22: Synthesis route of the ruthenium dye, S8 (taken from [40]).

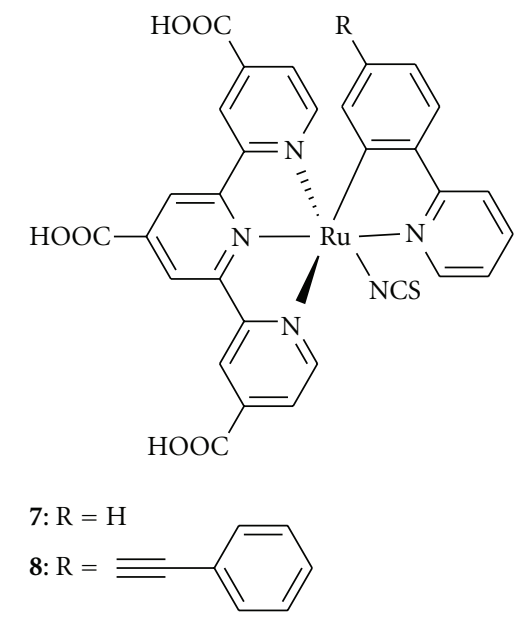

FIGURE 23: Molecular structures of cyclometallated ruthenium(II) complexes (taken from [41]).

Recently, a promising result has been obtained by replacing the thiocyanate with a cyclometallated 2,4-difluorophenylpyridine, yielding the complex YE05 (Figure 31) [53]. This novel ruthenium complex presents a promising class of robust and panchromatic sensitizers enabling greatly enhanced DSC performance.

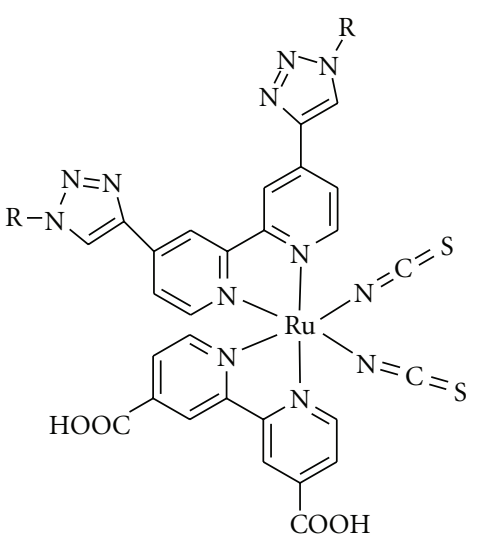<smiles>CCCCCCCOc1ccc(C#[R]#[W][Na])cc1</smiles>

Figure 24: Molecular structures of ruthenium(II) complexes JK-91 and JK-92 (taken from [42]).

The effects of replacing a single polypyridyl ligand with an analogous anionic cyclometalating ligand were investigated [54]. Electrochemical and spectroscopic methods were 


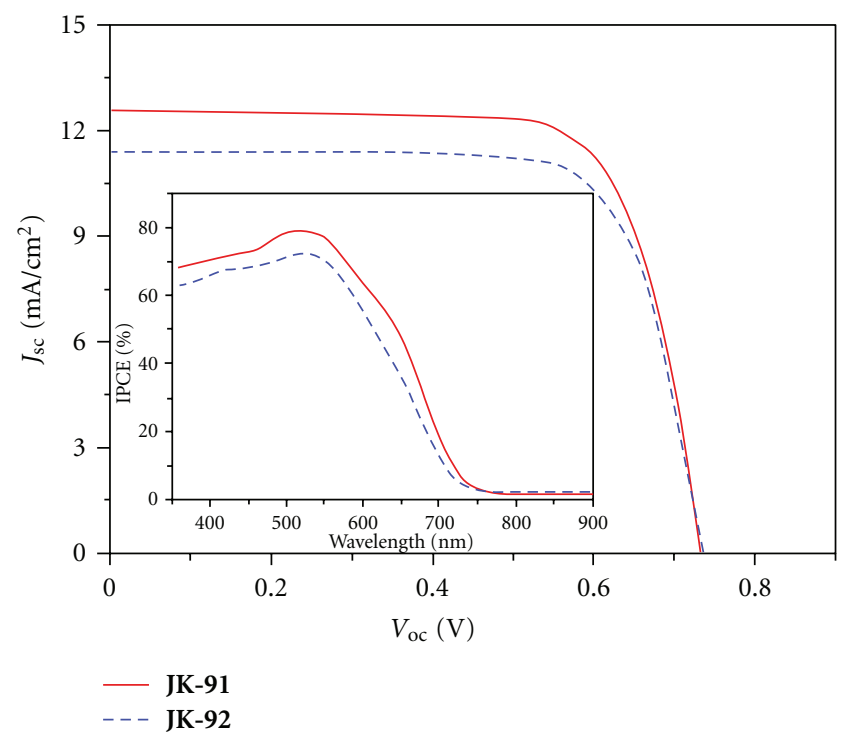

FIgURE 25: $I-V$ curves and IPCE spectra for JK-91 and JK-92 (taken from [42]).

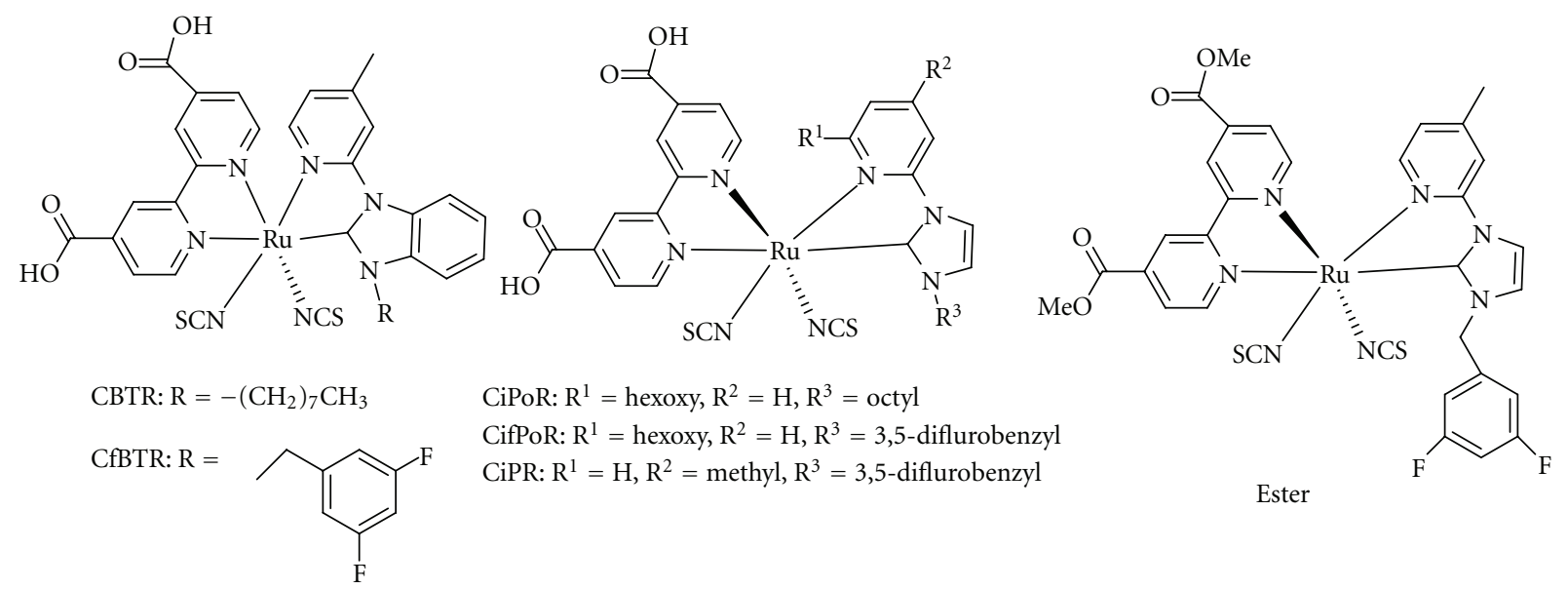

Figure 26: Molecular structure of the new sensitizers CBTR, CfBTR, CiPoR, CifPoR, CifPR, and ester (taken from [45, 46]).

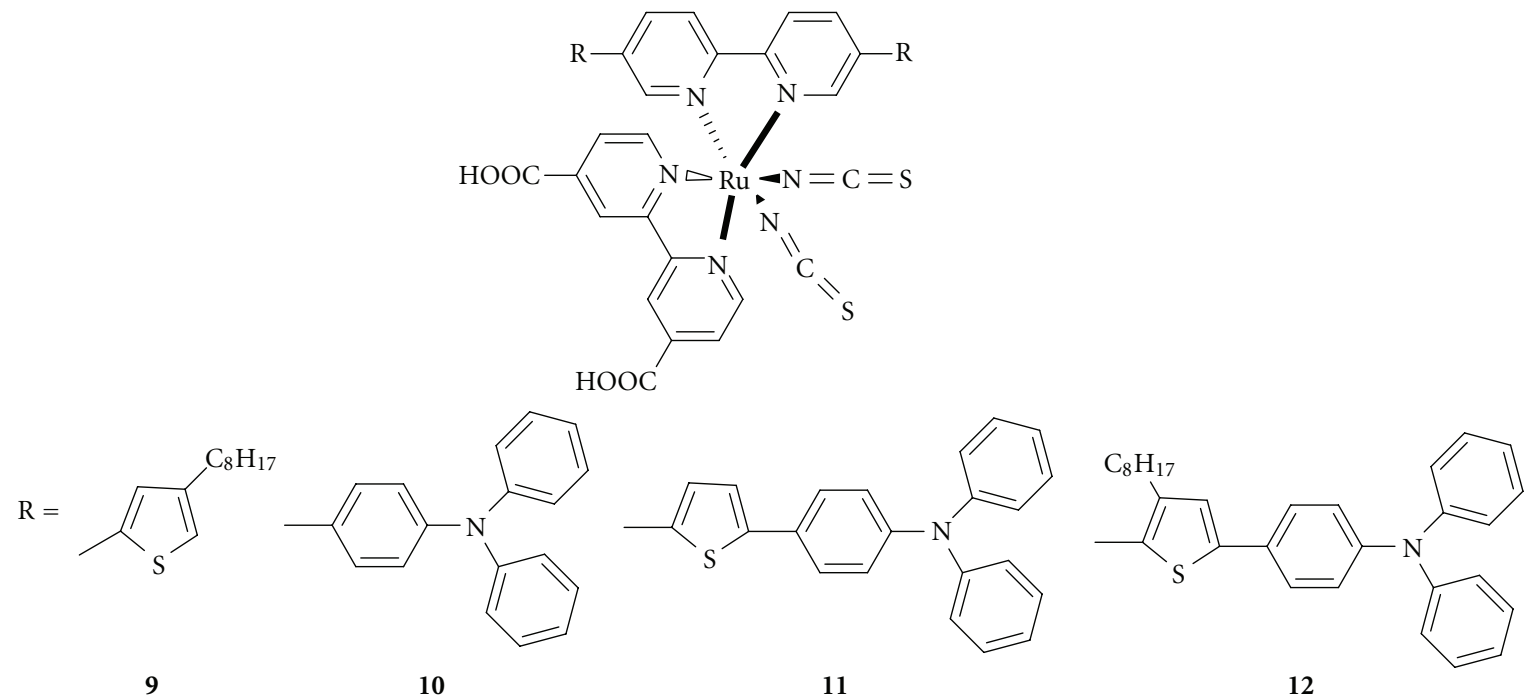

FIGURE 27: Molecular structures of ruthenium-based sensitizers 9-12 (taken from [47]). 


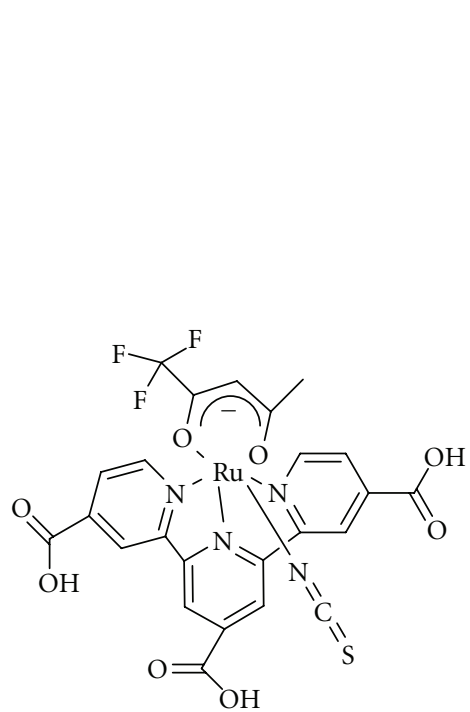

A1

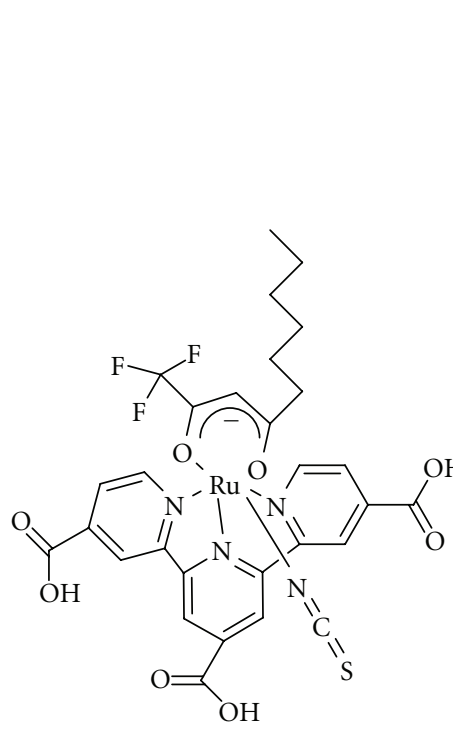

A2

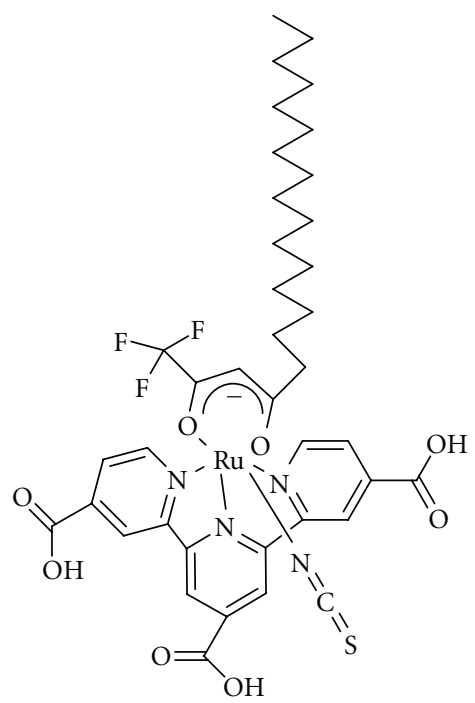

A3

Figure 28: Molecular structures of complexes A1, A2, and A3 (taken from [48]).<smiles></smiles>

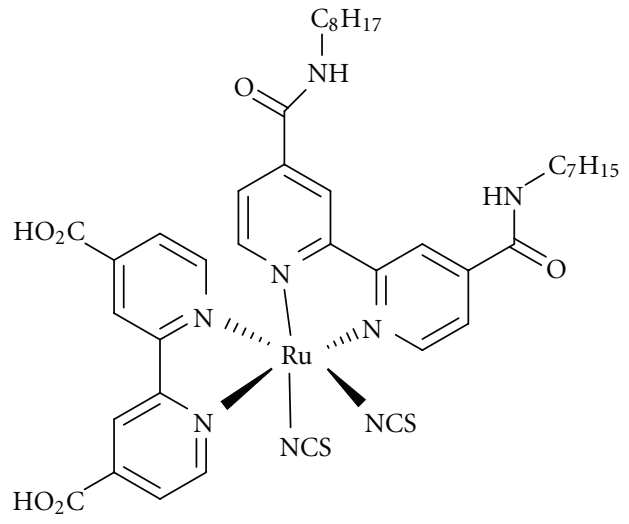

A597

Figure 29: Molecular structures of T18 (taken from [49]) and A597 (taken from [50]).

used to show that the strong $\sigma$-donating ability of cyclometalating ligands push the ground-state oxidation potentials of $\mathrm{Ru}$ (II) complexes to significantly higher energies. The response of the metal-to-ligand charge transfer band to variability in terminal substituents within a related set of tridentate polypyridyl and cyclometalated $\mathrm{Ru}(\mathrm{II})$ complexes was reported [55]. The cyclometalated species are more sensitive than their tpy-based congeners to substitution at the site para to the $\mathrm{Ru}-\mathrm{C}$ bond of the central ring.

To investigate the viability of cyclometalation as a general tool in the design of new sensitizers for dye-sensitized solar cells, a series of (cyclometalated) ruthenium complexes (Figure 32) was prepared [56]. The complexes with the C, $\mathrm{N}, \mathrm{N}^{\prime}$-bonding motif possess an excited state associated with the cyclometalated ligand, allowing efficient charge injection, while the complex with the $\mathrm{N}, \mathrm{C}, \mathrm{N}^{\prime}$-bonding motif possesses a more isolated excited state located on the remote tpy ligand. The red shift resulting from the introduction of a covalent carbon-to-ruthenium bond can be utilized as a tool to increase the red response of sensitizers for dye-sensitized solar cells.

It is important to understand the interfacial electron transfer pathways within such systems in which charge separation/recombination can be controlled by changing the electron-donor ability of ancillary bipyridyl ligands. Verma et al. [57] have studied the interfacial electron-transfer dynamics on $\mathrm{TiO}_{2}$ film sensitized with synthesized ruthenium(II)-polypyridyl complexes $\mathbf{1 7}$ and $\mathbf{1 8}$ (Figure 33) by using femtosecond transient absorption spectroscopy. They have observed significantly redshifted absorption spectra for complex 18 relative to complex $\mathbf{1 7}$ that were attributed to ligand-to-ligand charge-transfer states of complex 18. 


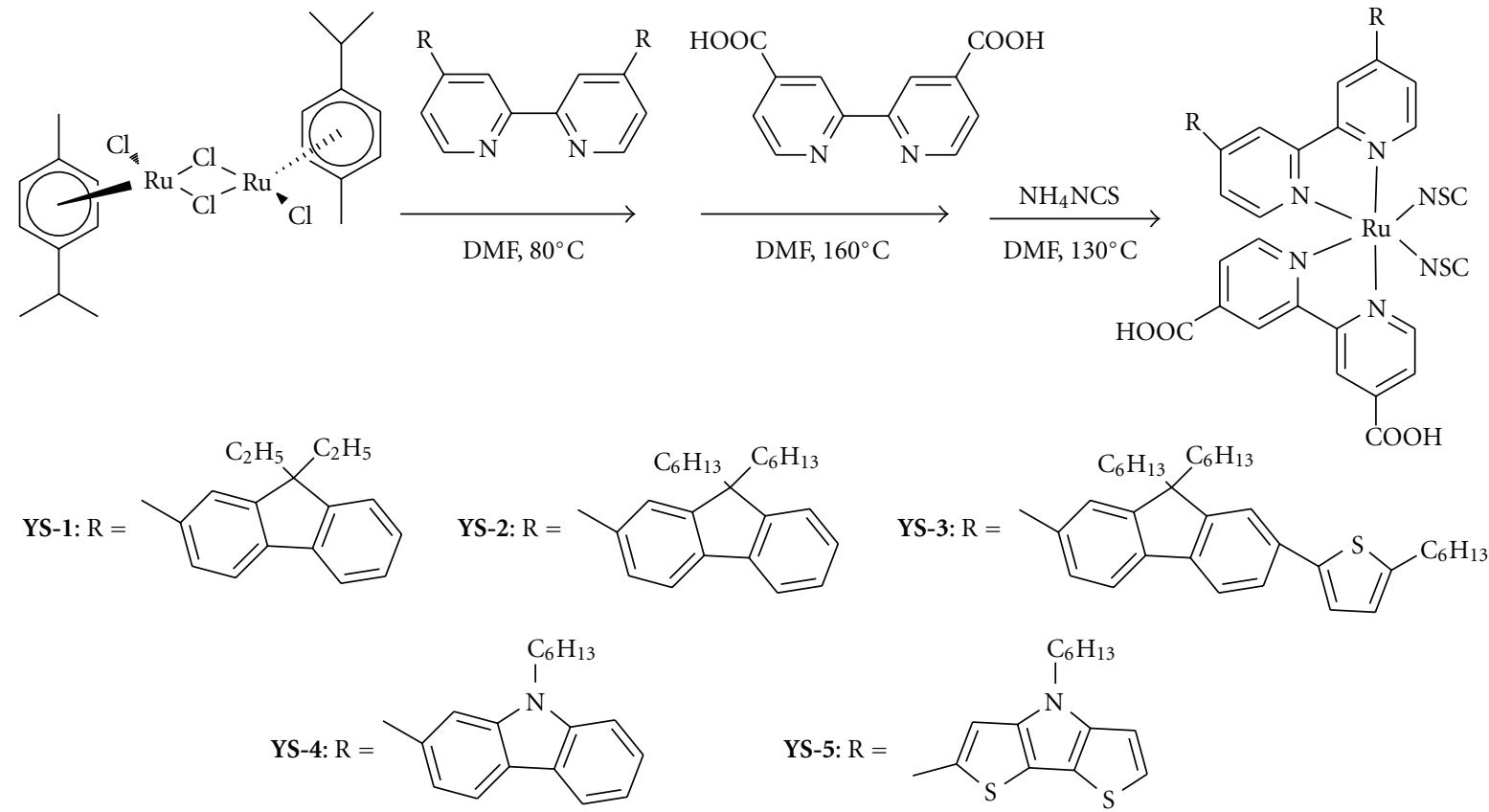

FIGURE 30: Synthesis routes of YS-1, YS-2, YS-3, YS-4, and YS-5 (taken from [51]).

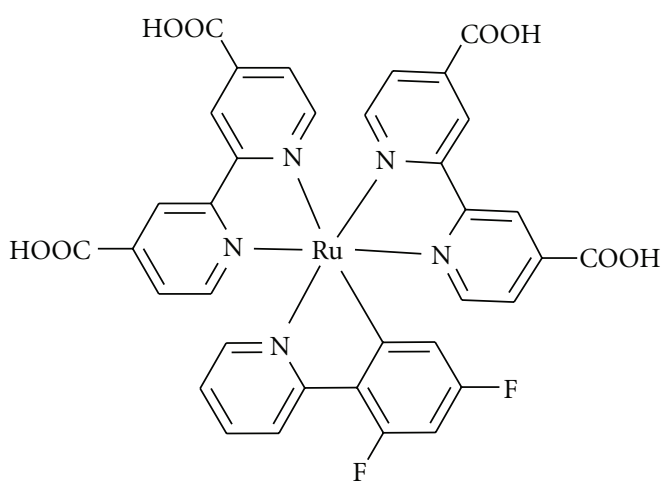

(a)

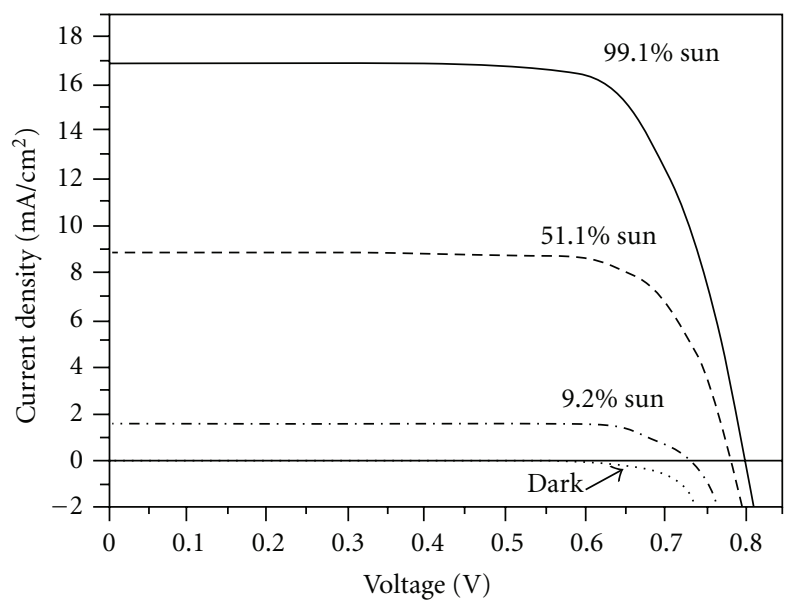

(b)

FIGURE 31: Molecular structure of YE05 and current density-voltage curves under various light intensities of AM 1.5 sunlight (taken from $[53])$.

A strategy that has proven to be effective for improving conventional dyes is the use of a tris-heteroleptic ligand environment. A series of tris-heteroleptic cyclometalated ruthenium(II) complexes were synthesized (Figure 34) and examined in the context of the development of efficient dye-sensitized solar cells [58]. It was shown that power conversion efficiencies $(\eta)$ range from 2.39 to $4.02 \%$ for 19 21.

The syntheses and electrochemical spectroscopic properties of a suite of asymmetrical bistridentate-cyclometalated $\mathrm{Ru}(\mathrm{II})$ complexes (Figure 35) bearing terminal triphenylamine (TPA) substituents were reported [59]. The placement of the anionic ring on the flanking position of the tridentate ligand proximate to the TPA unit maximizes light harvesting in the visible region, maintains sufficient vectoral electron transfer toward the semiconductor surface, and ensures that the LUMO is situated on the anchoring ligand to enable facile charge injection into the $\mathrm{TiO}_{2}$. This study also highlights the ability to independently manipulate the thermodynamic energy levels of the redox-active TPA and metal units.

In order to engineer new ruthenium-based dyes as strong light absorbers and efficient dyes for DSSCs, Kisserwan and Ghaddar [60] investigated a new cyclometalated ruthenium 


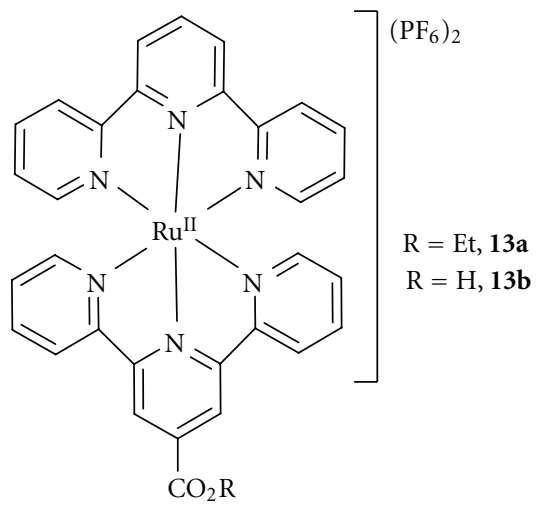

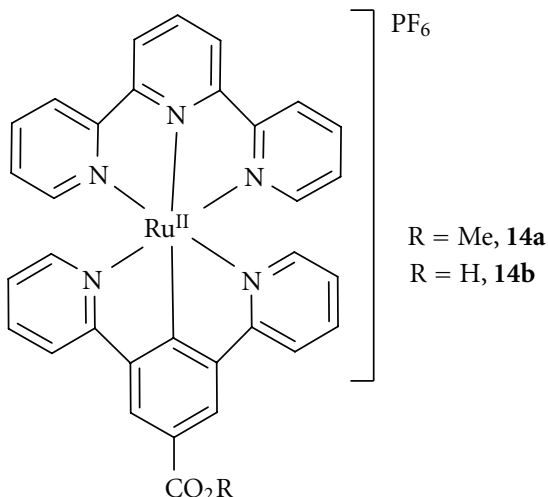

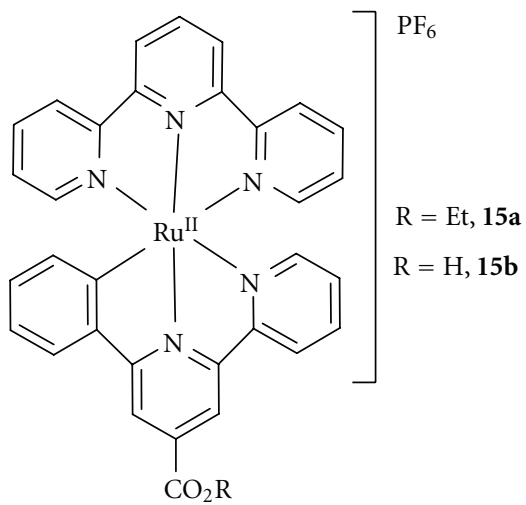

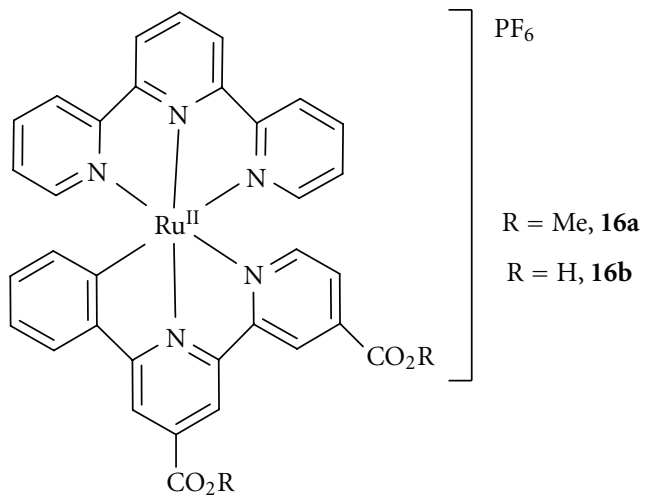

Figure 32: Molecular structures of 13-16 (taken from [56]).

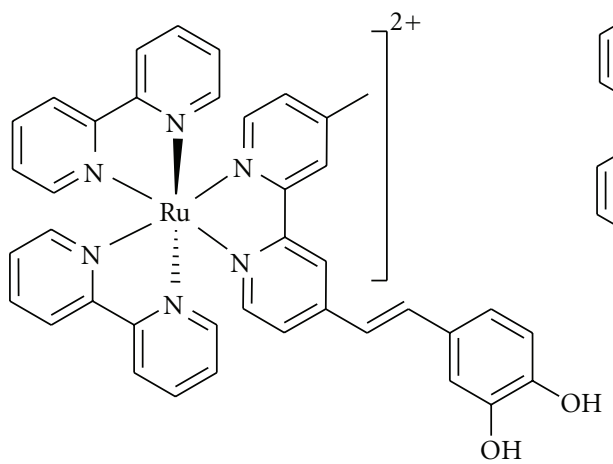

17

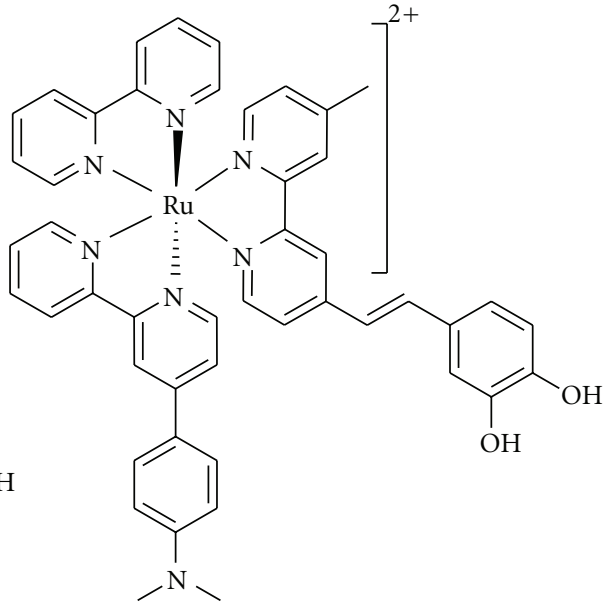

18

FIGURE 33: Molecular structure of 17 and $\mathbf{1 8}$ (taken from [57]).

complex T66 (Figure 36) and incorporated it as a sensitizer in a DSSC. Efficiency of 4.5\% has been measured for T66 in a nonvolatile ionic liquid-based electrolyte.

A new series of neutral, thiocyanate-free $\mathrm{Ru}(\mathrm{II})$ sensitizers (TFRS-1-3) (Figure 37), which are assembled using both $4,4^{\prime}$-carboxy-2,2'-bypyridine and 2-pyridyl pyrazolate ancillaries, exhibit a light-harvesting capability up to $700 \mathrm{~nm}$ and superior DSSC performance in conversion efficiency [61]. The highest power conversion efficiencies are close to $9.5 \%$ for TFRS-2. This result eliminates the need for proximal contact between the soft sulfur atom of thiocyanate and electron donor in electrolyte for effective regeneration of dyes. Further development is versatile and of great perspective. 


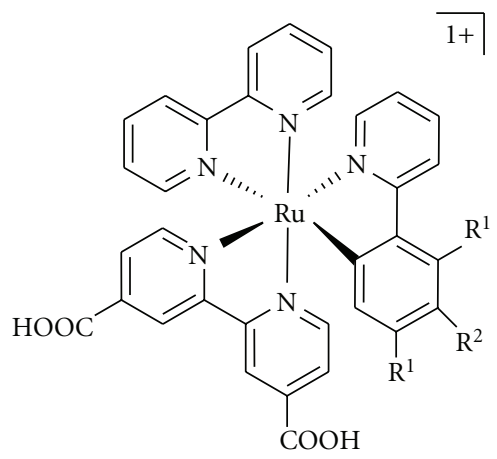

$$
\begin{aligned}
& \text { 19: } \mathrm{R}^{1}=\mathrm{H}, \mathrm{R}^{2}=\mathrm{H} \\
& \text { 20: } \mathrm{R}^{1}=\mathrm{F}, \mathrm{R}^{2}=\mathrm{H} \\
& \text { 21: } \mathrm{R}^{1}=\mathrm{H}, \mathrm{R}^{2}=
\end{aligned}
$$

Figure 34: Molecular structures of 19-21 (taken from [58]).

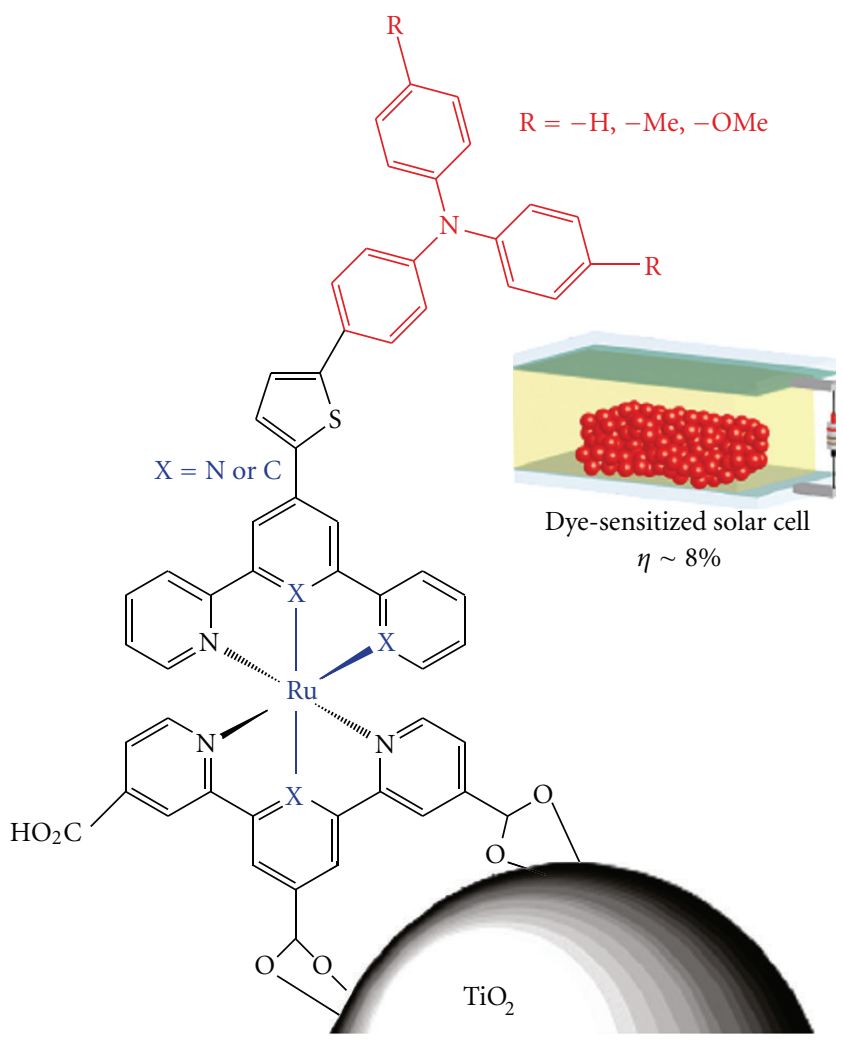

FIGURE 35: Bistridentate cyclometalated Ru(II) complexes in DSSC (taken from [59]).

\section{Conclusions and Perspective}

In this paper, we reviewed on recent advances in ruthenium sensitizers and their applications in DSSCs, including thiocyanate ruthenium sensitizers and thiocyanate-free ruthenium sensitizers. Ru complexes have shown the good photovoltaic properties: a broad absorption spectrum, suit- able excited and ground state energy levels, relatively long excited-state lifetime, and good (electro)chemical stability. The thiocyanate ligands are usually considered as the most fragile part of the ruthenium dyes. And many attempts to replace the thiocyanate donor ligands have been made, and these efforts have yielded only limited success. Many efforts have been made to design the ligands of Ru complexes and 


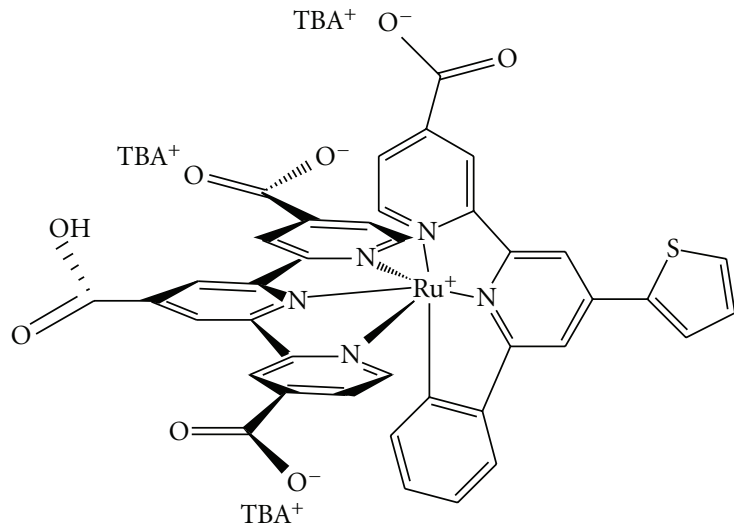

(a)

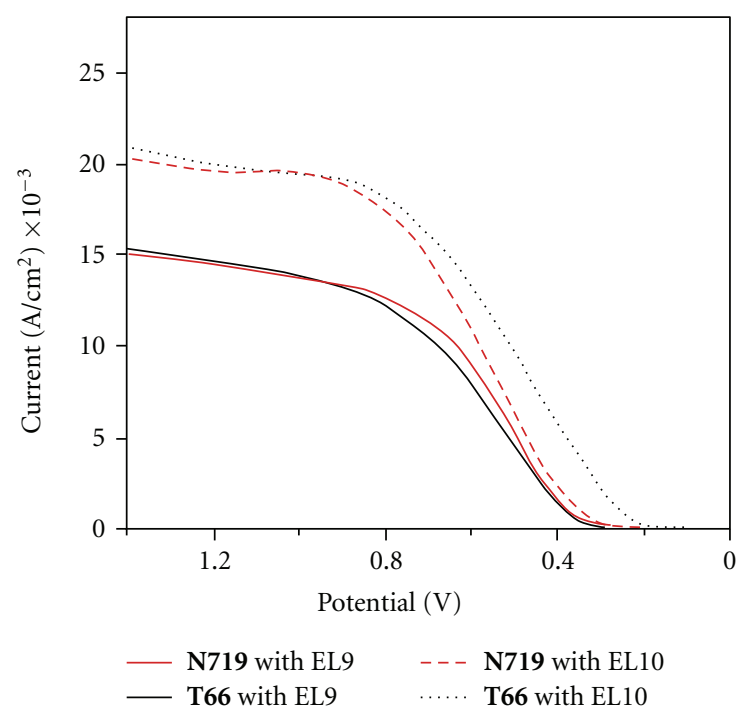

(b)

FIgURE 36: Molecular structure of T66 and current-potential curves of assembled DSSC (taken from [60]).

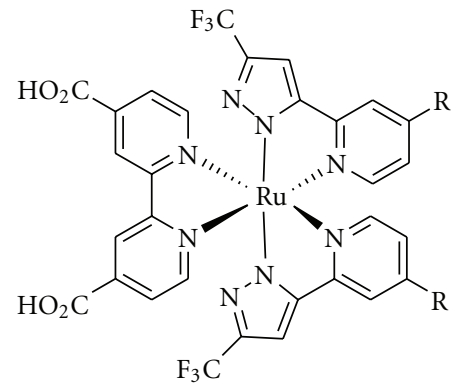

TFRS-1: $\mathrm{R}=\mathrm{H}$

TFRS-2: $\mathrm{R}=$

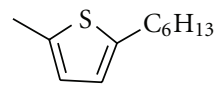

TFRS-3: $\mathrm{R}=$<smiles>CCCCCCc1ccc(-c2ccc(C)s2)s1</smiles>

(a)

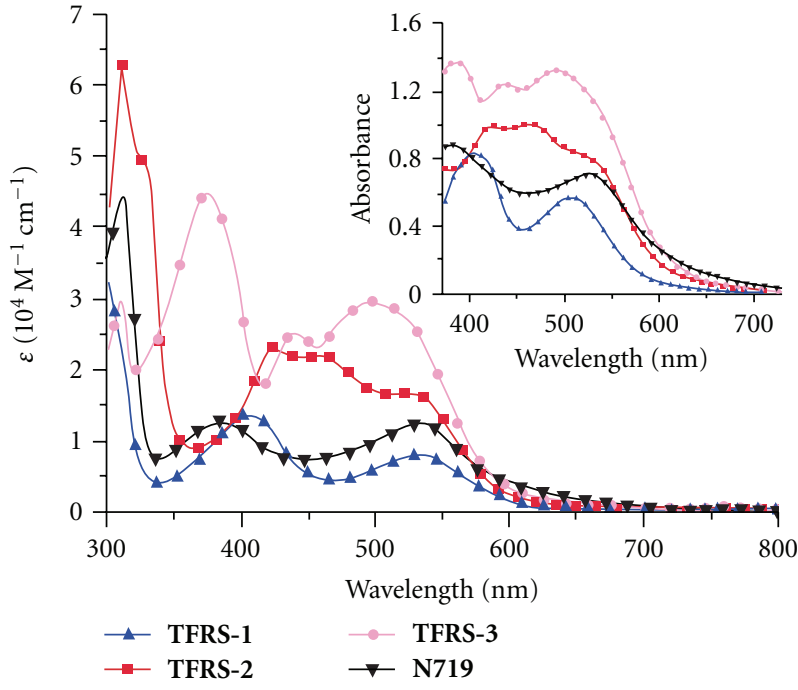

(b)

FIGURE 37: Molecular structures of Ru(II) sensitizers TFRS-1-3 and absorption spectra of TFRS, N719 in DMF (taken from [61]).

optimize the photosensitizers. Several Ru complexes used in DSSCs have reached more than $10 \%$ solar cell efficiency under standard measurement conditions.

A commercial challenging but realizable goal for the present DSSC technology is to achieve efficiencies above $15 \%$. Future improvement will focus on the $J_{\mathrm{SC}}$ by extending the light response of the sensitizers in the near IR spectral region. The design new ligands leading to the preparation of new ruthenium sensitizers is a convenient and versatile new route to achieve high efficiencies. The further work will be targeted to extend the conjugated system of ligand and a slightly longer hydrocarbon chain length might be advantageous and could lead to even higher efficiencies, and a hydrophobic chain attached to the dye can be used to suppress recombination. In the design and synthesis of novel and efficient organic dyes for DSSCs, this should be kept in mind of the researchers all along.

\section{Acknowledgments}

The work was financially supported by the Natural Science Foundation of China (Grant no. 20802033), Program for New Century Excellent Talents in University (Grant no. NCET-10-0170), Yong Scientist of Jing Gang Zhi Xing 
Project of Jiangxi Province (Grant no. 2008DQ00700), Natural Science Foundation of Jiangxi Province (Grant no. 2010GZH0110), Scientific Research Foundation of Nanchang Hangkong University (no. EA200802012, EA201102178), and Sichuan University.

\section{References}

[1] N. Lior, "Energy resources and use: the present situation and possible paths to the future," Energy, vol. 33, no. 6, pp. 842857, 2008.

[2] M. Grätzel, "Photoelectrochemical cells," Nature, vol. 414, no. 6861, pp. 338-344, 2001.

[3] Y. Ooyama and Y. Harima, "Molecular designs and syntheses of organic dyes for dye-sensitized solar cells," European Journal of Organic Chemistry, no. 18, pp. 2903-2934, 2009.

[4] A. Mishra, M. K. R. Fischer, and P. Büuerle, "Metal-free organic dyes for dye-Sensitized solar cells: from structure: property relationships to design rules," Angewandte Chemie, vol. 48, no. 14, pp. 2474-2499, 2009.

[5] F. Bonaccorso, "Debundling and selective enrichment of swnts for applications in dye-sensitized solar cells," International Journal of Photoenergy, vol. 2010, Article ID 727134, 14 pages, 2010.

[6] S. Caramori, V. Cristino, R. Boaretto et al., "New components for dye-sensitized solar cells," International Journal of Photoenergy, vol. 2010, Article ID 458614, 16 pages, 2010.

[7] A. Hagfeldt, G. Boschloo, L. Sun, L. Kloo, and H. Pettersson, "Dye-sensitized solar cells," Chemical Reviews, vol. 110, no. 11, pp. 6595-6663, 2010.

[8] M. K. Nazeeruddin, E. Baranoff, and M. Grätzel, "Dyesensitized solar cells: a brief overview," Solar Energy, vol. 85, no. 6, pp. 1172-1178, 2011.

[9] B. O'Regan and M. Grätzel, "A low-cost, high-efficiency solar cell based on dye-sensitized colloidal $\mathrm{TiO}_{2}$ films," Nature, vol. 353, no. 6346, pp. 737-740, 1991.

[10] C. Li, M. Liu, N. G. Pschirer, M. Baumgarten, and K. Müllen, "Polyphenylene-based materials for organic photovoltaics," Chemical Reviews, vol. 110, no. 11, pp. 6817-6855, 2010.

[11] O. Kohle, M. Grätzel, A. F. Meyer, and T. B. Meyer, "The photovoltaic stability of bis(isothiocyanato)ruthenium(II)-bis-2,2' bipyridine-4,4' - dicarboxylic acid and related sensitizers," Advanced Materials, vol. 9, no. 11, pp. 904-906, 1997.

[12] M. K. Nazeeruddin, P. Péchy, T. Renouard et al., "Engineering of efficient panchromatic sensitizers for nanocrystalline $\mathrm{TiO}_{2}$ based solar cells," Journal of the American Chemical Society, vol. 123, no. 8, pp. 1613-1624, 2001.

[13] M. K. Nazeeruddin, A. Kay, I. Rodicio et al., "Conversion of light to electricity by cis- $\mathrm{X}_{2}$ bis $\left(2,2^{\prime}\right.$-bipyridyl-4,4'dicarboxylate)ruthenium(II) charge-transfer sensitizers ( $\mathrm{X}=$ $\mathrm{Cl}^{-}, \mathrm{Br}^{-}, \mathrm{I}^{-}, \mathrm{CN}^{-}$, and $\mathrm{SCN}^{-}$) on nanocrystalline $\mathrm{TiO}_{2}$ electrodes," Journal of the American Chemical Society, vol. 115, no. 14, pp. 6382-6390, 1993.

[14] M. K. Nazeeruddin, P. Péchy, and M. Grätzel, "Efficient panchromatic sensitization of nanocrystalline $\mathrm{TiO}_{2}$ films by a black dye based on a trithiocyanato-ruthenium complex," Chemical Communications, no. 18, pp. 1705-1706, 1997.

[15] U. Bach, D. Lupo, P. Comte et al., "Solid-state dye-sensitized mesoporous $\mathrm{TiO}_{2}$ solar cells with high photon-to-electron conversion efficiencies," Nature, vol. 395, no. 6702, pp. 583$585,1998$.

[16] P. Wang, S. M. Zakeeruddin, J. E. Moser, M. K. Nazeeruddin, T. Sekiguchi, and M. Grätzel, "A stable quasi-solid-state dye-sensitized solar cell with an amphiphilic ruthenium sensitizer and polymer gel electrolyte," Nature Materials, vol. 2, no. 6, pp. 402-407, 2003.

[17] P. Wang, S. M. Zakeeruddin, R. Humphry-Baker, J. E. Moser, and M. Grätzel, "Molecular-scale interface engineering of $\mathrm{TiO}_{2}$ nanocrystals: improving the efficiency and stability of dye-sensitized solar cells," Advanced Materials, vol. 15, no. 24, pp. 2101-2104, 2003.

[18] P. Wang, B. Wenger, R. Humphry-Baker et al., "Charge separation and efficient light energy conversion in sensitized mesoscopic solar cells based on binary ionic liquids," Journal of the American Chemical Society, vol. 127, no. 18, pp. 68506856, 2005.

[19] M. K. Nazeeruddin, R. Splivallo, P. Liska, P. Comte, and M. Grätzel, "A swift dye uptake procedure for dye sensitized solar cells," Chemical Communications, vol. 9, no. 12, pp. 14561457, 2003.

[20] P. Wang, R. Humphry-Baker, J. E. Moser, S. M. Zakeeruddin, and M. Grätzel, "Amphiphilic polypyridyl ruthenium complexes with substituted 2,2'-dipyridylamine ligands for nanocrystalline dye-sensitized solar cells," Chemistry of Materials, vol. 16, no. 17, pp. 3246-3251, 2004.

[21] P. Wang, S. M. Zakeeruddin, J. E. Moser et al., "Stable new sensitizer with improved light harvesting for nanocrystalline dye-sensitized solar cells," Advanced Materials, vol. 16, no. 20, pp. 1806-1811, 2004.

[22] M. K. Nazeeruddin, F. De Angelis, S. Fantacci et al., "Combined experimental and DFT-TDDFT computational study of photoelectrochemical cell ruthenium sensitizers," Journal of the American Chemical Society, vol. 127, no. 48, pp. 1683516847, 2005.

[23] P. Wang, C. Klein, R. Humphry-Baker, S. M. Zakeeruddin, and M. Grätzel, "A high molar extinction coefficient sensitizer for stable dye-sensitized solar cells," Journal of the American Chemical Society, vol. 127, no. 3, pp. 808-809, 2005.

[24] L. Schmidt-Mende, J. E. Kroeze, J. R. Durrant, M. K. Nazeeruddin, and M. Grätzel, "Effect of hydrocarbon chain length of amphiphilic ruthenium dyes on solid-state dyesensitized photovoltaics," Nano Letters, vol. 5, no. 7, pp. 13151320, 2005.

[25] D. Kuang, C. Klein, H. J. Snaith et al., "Ion coordinating sensitizer for high efficiency mesoscopic dye-sensitized solar cells: influence of lithium ions on the photovoltaic performance of liquid and solid-state cells," Nano Letters, vol. 6, no. 4, pp. 769$773,2006$.

[26] D. Kuang, C. Klein, S. Ito et al., "High molar extinction coefficient ion-coordinating ruthenium sensitizer for efficient and stable mesoscopic dye-sensitized solar cells," Advanced Functional Materials, vol. 17, no. 1, pp. 154-160, 2007.

[27] D. Kuang, C. Klein, H. J. Snaith, R. Humphry-Baker, S. M. Zakeeruddin, and M. Grätzel, "A new ion-coordinating ruthenium sensitizer for mesoscopic dye-sensitized solar cells," Inorganica Chimica Acta, vol. 361, no. 3, pp. 699-706, 2008.

[28] D. Kuang, S. Ito, B. Wenger et al., "High molar extinction coefficient heteroleptic ruthenium complexes for thin film dye-sensitized solar cells," Journal of the American Chemical Society, vol. 128, no. 12, pp. 4146-4154, 2006.

[29] Q. Wang, S. M. Zakeeruddin, M. K. Nazeeruddin, R. Humphry-Baker, and M. Grätzel, "Molecular wiring of nanocrystals: NCS-enhanced cross-surface charge transfer in self-assembled Ru-complex monolayer on mesoscopic oxide films," Journal of the American Chemical Society, vol. 128, no. 13, pp. 4446-4452, 2006. 
[30] S. R. Jang, C. Lee, H. Choi et al., "Oligophenylenevinylenefunctionalized $\mathrm{Ru}(\mathrm{II})$-bipyridine sensitizers for efficient dyesensitized nanocrystalline $\mathrm{TiO}_{2}$ solar cells," Chemistry of Materials, vol. 18, no. 23, pp. 5604-5608, 2006.

[31] C. Y. Chen, S. J. Wu, C. G. Wu, J. G. Chen, and K. C. Ho, "A ruthenium complex with superhigh light-harvesting capacity for dye-sensitized solar cells," Angewandte Chemie, vol. 45, no. 35, pp. 5822-5825, 2006.

[32] K. J. Jiang, N. Masaki, J. B. Xia, S. Noda, and S. Yanagida, "A novel ruthenium sensitizer with a hydrophobic 2-thiophen2-yl-vinyl- conjugated bipyridyl ligand for effective dye sensitized $\mathrm{TiO}_{2}$ solar cells," Chemical Communications, no. 23, pp. 2460-2462, 2006.

[33] R. Kawano, M. K. Nazeeruddin, A. Sato, M. Grätzel, and M. Watanabe, "Amphiphilic ruthenium dye as an ideal sensitizer in conversion of light to electricity using ionic liquid crystal electrolyte," Electrochemistry Communications, vol. 9, no. 5, pp. 1134-1138, 2007.

[34] F. De Angelis, S. Fantacci, A. Selloni, M. K. Nazeeruddin, and M. Grätzel, "Time-dependent density functional theory investigations on the excited states of $\mathrm{Ru}(\mathrm{II})$-dye-sensitized $\mathrm{TiO}_{2}$ nanoparticles: the role of sensitizer protonation," Journal of the American Chemical Society, vol. 129, no. 46, pp. 14156-14157, 2007.

[35] C. S. Karthikeyan, H. Wietasch, and M. Thelakkat, "Highly efficient solid-state dye-sensitized $\mathrm{TiO}_{2}$ solar cells using donor-antenna dyes capable of multistep charge-transfer cascades," Advanced Materials, vol. 19, no. 8, pp. 1091-1095, 2007.

[36] D. Kuang, C. Klein, S. Ito et al., "High-efficiency and stable mesoscopic dye-sensitized solar cells based on a high molar extinction coefficient ruthenium sensitizer and nonvolatile electrolyte," Advanced Materials, vol. 19, no. 8, pp. 1133-1137, 2007.

[37] C. Y. Chen, S. J. Wu, J. Y. Li, C. G. Wu, J. G. Chen, and K. C. Ho, "A new route to enhance the light-harvesting capability of ruthenium complexes for dye-sensitized solar cells," Advanced Materials, vol. 19, no. 22, pp. 3888-3891, 2007.

[38] F. Gao, Y. Wang, D. Shi et al., "Enhance the optical absorptivity of nanocrystalline $\mathrm{TiO}_{2}$ film with high molar extinction coefficient ruthenium sensitizers for high performance dyesensitized solar cells," Journal of the American Chemical Society, vol. 130, no. 32, pp. 10720-10728, 2008.

[39] K. L. McCall, J. R. Jennings, H. Wang et al., "Novel ruthenium bipyridyl dyes with S-donor ligands and their application in dye-sensitized solar cells," Journal of Photochemistry and Photobiology A, vol. 202, no. 2-3, pp. 196-204, 2009.

[40] H. K. Song, Y. H. Park, C. H. Han, and J. G. Jee, "Synthesis of ruthenium complex and its application in dye-sensitized solar cells," Journal of Industrial and Engineering Chemistry, vol. 15, no. 1, pp. 62-65, 2009.

[41] T. Funaki, M. Yanagida, N. Onozawa-Komatsuzaki et al., "Synthesis of a new class of cyclometallated ruthenium(II) complexes and their application in dye-sensitized solar cells," Inorganic Chemistry Communications, vol. 12, no. 9, pp. 842845, 2009.

[42] S. Paek, C. Baik, M. S. Kang, H. Kang, and J. Ko, "New type of ruthenium sensitizers with a triazole moiety as a bridging group," Journal of Organometallic Chemistry, vol. 695, no. 6, pp. 821-826, 2010.

[43] A. J. Arduengo III, R. L. Harlow, and M. Kline, "A stable crystalline carbene," Journal of the American Chemical Society, vol. 113, no. 1, pp. 361-363, 1991.
[44] P. de Frémont, N. Marion, and S. P. Nolan, "Carbenes: synthesis, properties, and organometallic chemistry," Coordination Chemistry Reviews, vol. 253, no. 7-8, pp. 862-892, 2009.

[45] W. C. Chang, H. S. Chen, T. Y. Li et al., "Highly efficient N-heterocyclic carbene/pyridine-based ruthenium sensitizers: complexes for dye-sensitized solar cells," Angewandte Chemie, vol. 49, no. 44, pp. 8161-8164, 2010.

[46] H.-S. Chen, W.-C. Chang, C. Su et al., "Carbene-based ruthenium photosensitizers," Dalton Transactions, vol. 40, no. 25, pp. 6765-6770, 2011.

[47] F.-R. Dai, W.-J. Wu, Q.-W. Wang, H. Tian, and W.-Y. Wong, "Heteroleptic ruthenium complexes containing uncommon 5,5' - disubstituted-2,2'-bipyridine chromophores for dyesensitized solar cells," Dalton Transactions, vol. 40, no. 10, pp. 2314-2323, 2011.

[48] A. Islam, S. P. Singh, M. Yanagida, M. R. Karim, and L. Han, "Amphiphilic ruthenium(II) terpyridine sensitizers with long alkyl chain substituted $\beta$-diketonato ligands: an efficient coadsorbent-free dye-sensitized solar cells," International Journal of Photoenergy, vol. 2011, Article ID 757421, 7 pages, 2011.

[49] H. Kisserwan and T. H. Ghaddar, "Enhancement of photovoltaic performance of a novel dye, "T18", with ketene thioacetal groups as electron donors for high efficiency dye-sensitized solar cells," Inorganica Chimica Acta, vol. 363, no. 11, pp. 2409-2415, 2010.

[50] A. J. Hallett and J. E. Jones, "Purification-free synthesis of a highly efficient ruthenium dye complex for dye-sensitised solar cells (DSSCs)," Dalton Transactions, vol. 40, no. 15, pp. 3871-3876, 2011.

[51] Y.-S. Yen, Y.-C. Chen, Y.-C. Hsu, H.-H. Chou, J. T. Lin, and D.-J. Yin, "Heteroleptic ruthenium sensitizers that contain an ancillary bipyridine ligand tethered with hydrocarbon chains for efficient dye-sensitized solar cells," Chemistry, vol. 17, no. 24, pp. 6781-6788, 2011.

[52] S. H. Wadman, J. M. Kroon, K. Bakker et al., "Cyclometalated ruthenium complexes for sensitizing nanocrystalline $\mathrm{TiO}_{2}$ solar cells," Chemical Communications, no. 19, pp. 1907-1909, 2007.

[53] T. Bessho, E. Yoneda, J. H. Yum et al., "New paradigm in molecular engineering of sensitizers for solar cell applications," Journal of the American Chemical Society, vol. 131, no. 16, pp. 5930-5934, 2009.

[54] P. G. Bomben, K. C. D. Robson, P. A. Sedach, and C. P. Berlinguette, "On the viability of cyclometalated $\mathrm{Ru}(\mathrm{II})$ complexes for light-harvesting applications," Inorganic Chemistry, vol. 48, no. 20, pp. 9631-9643, 2009.

[55] B. D. Koivisto, K. C. D. Robson, and C. P. Berlinguette, "Systematic manipulation of the light-harvesting properties for tridentate cyclometalated ruthenium(II) complexes," Inorganic Chemistry, vol. 48, no. 20, pp. 9644-9652, 2009.

[56] S. H. Wadman, J. M. Kroon, and K. Bakker, "Cyclometalated organoruthenium complexes for application in dye-sensitized solar cells," Organometallics, vol. 29, no. 7, pp. 1569-1579, 2010.

[57] S. Verma, P. Kar, A. Das, and H. N. Ghosh, "Efficient charge separation in $\mathrm{TiO}_{2}$ films sensitized with ruthenium(II)polypyridyl complexes: hole stabilization by ligand-localized charge-transfer states," Chemistry, vol. 17, no. 5, pp. 15611568, 2011.

[58] P. G. Bomben, K. D. Thériault, and C. P. Berlinguette, "Strategies for optimizing the performance of cyclometalated ruthenium sensitizers for dye-sensitized solar cells," European Journal of Inorganic Chemistry, vol. 2011, no. 11, pp. 18061814, 2011. 
[59] K. C. D. Robson, B. D. Koivisto, A. Yella et al., "Design and development of functionalized cyclometalated ruthenium chromophores for light-harvesting applications," Inorganic Chemistry, vol. 50, no. 12, pp. 5494-5508, 2011.

[60] H. Kisserwan and T. H. Ghaddar, "Enhancement of photocurrent in dye sensitized solar cells incorporating a cyclometalated ruthenium complex with cuprous iodide as an electrolyte additive," Dalton Transactions, vol. 40, no. 15, pp. 3877-3884, 2011.

[61] K. L. Wu, H. C. Hsu, K. Chen et al., "Development of thiocyanate-free, charge-neutral $\mathrm{Ru}(\mathrm{II})$ sensitizers for dye-sensitized solar cells," Chemical Communications, vol. 46, no. 28, pp. 5124-5126, 2010. 


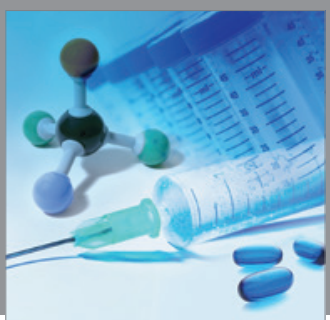

International Journal of

Medicinal Chemistry

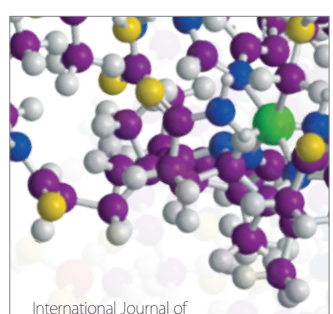

Carbohydrate Chemistry

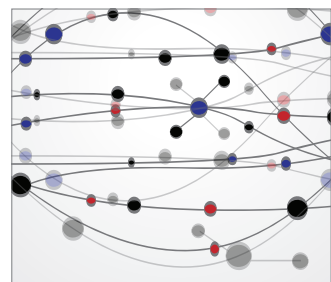

The Scientific World Journal
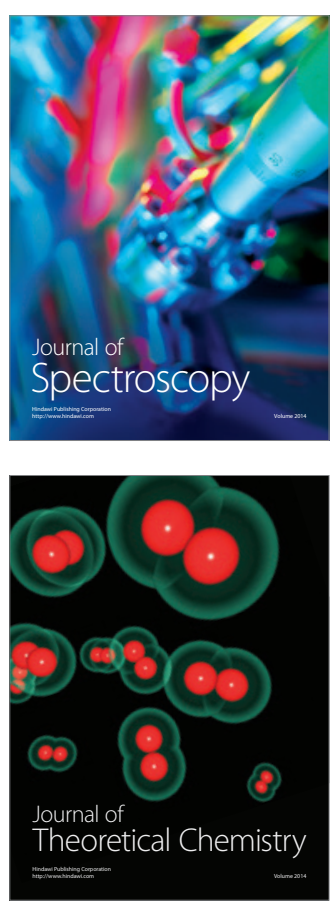
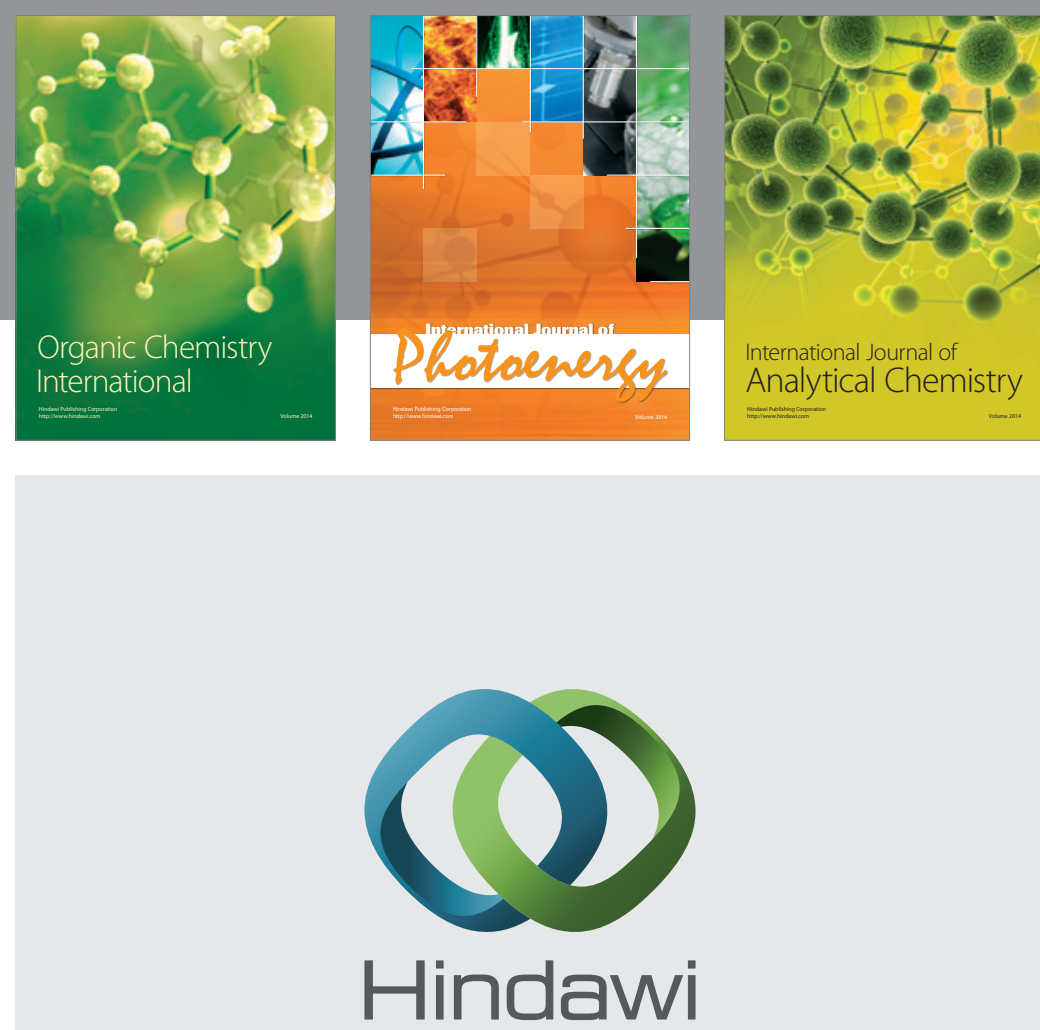

Submit your manuscripts at

http://www.hindawi.com
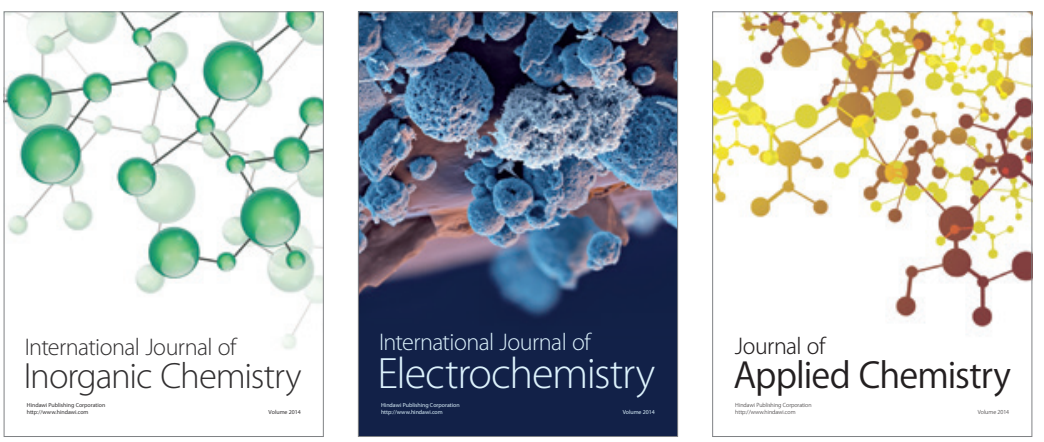

Journal of

Applied Chemistry
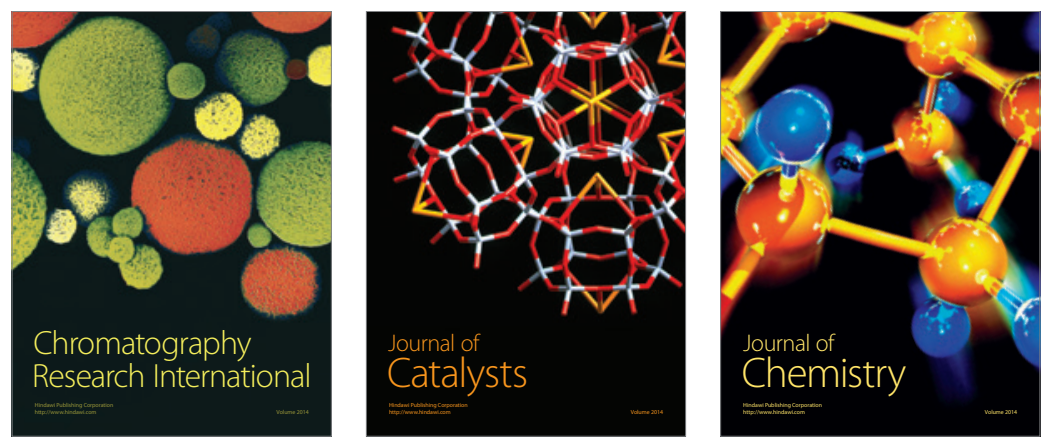
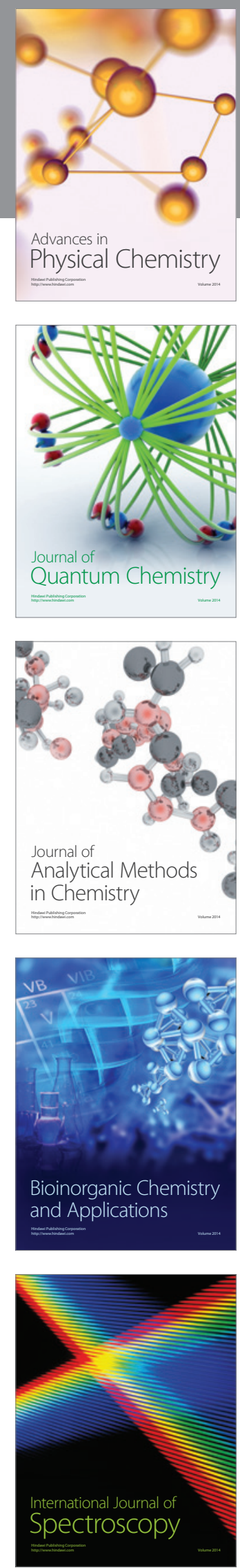